i.

\title{
Continuous Concentration and Constant Volume Washing of Tetraphenylborate Slurries
}

by

J. L. Siler

Westinghouse Savannah River Company

Savannah River Site

Aiken, South Carolina 29808

M. R. Poirier

DOE Contract No. DE-AC09-96SR18500

This paper was prepared in connection with work done under the above contract number with the U.S. Department of Energy. By acceptance of this paper, the publisher and/or recipient acknowledges the U.S. Government's right to retain a nonexclusive, royalty-free license in and to any copyright covering this paper, along with the right to reproduce and to authorize others to reproduce all or part of the copyrighted paper. 
This document was prepared in conjunction with work accomplished under Contract No.

DE-AC09-96SR18500 with the U.S. Department of Energy.

\section{DISCLAIMER}

This report was prepared as an account of work sponsored by an agency of the United States Government. Neither the United States Government nor any agency thereof, nor any of their employees, makes any warranty, express or implied, or assumes any legal liability or responsibility for the accuracy, completeness, or usefulness of any information, apparatus, product or process disclosed, or represents that its use would not infringe privately owned rights. Reference herein to any specific commercial product, process or service by trade name, trademark, manufacturer, or otherwise does not necessarily constitute or imply its endorsement, recommendation, or favoring by the United States Government or any agency thereof. The views and opinions of authors expressed herein do not necessarily state or reflect those of the United States Government or any agency thereof.

This report has been reproduced directly from the best available copy.

Available for sale to the public, in paper, from: U.S. Department of Commerce, National Technical Information Service, 5285 Port Royal Road, Springfield, VA 22161, phone: (800) 553-6847,

fax: (703) 605-6900

email: orders@ntis.fedworld.gov

online ordering: http://www.ntis.gov/ordering.htm

Available electronically at http://www.doe.gov/bridge

Available for a processing fee to U.S. Department of Energy and its contractors, in paper, from: U.S. Department of Energy, Office of Scientific and Technical Information, P.O. Box 62, Oak Ridge, TN 37831-0062, phone: (865)576-8401, fax: (865)576-5728

email: reports@adonis.osti.gov 


\section{DISCLAIMER}

Portions of this document may be illegible in electronic image products. Images are produced from the best available original document. 
WSRC-TR-99-00243

Revision 0

Key Words:

Filtration

Tetraphenylborate

Retention:

Permanent

\title{
Continuous Concentration and Constant Volume Washing of Tetraphenylborate Slurries
}

\author{
M.R. Poirier \\ J.L. Siler \\ Westinghouse Savannah River Company \\ Savannah River Technology Center \\ Aiken, SC 29808
}

August 5, 1999 
WSRC-TR-99-00243, Rev.0

August 5, 1999

REVIEWS and APPROVALS

$\begin{array}{ll}\text { Tinebal Ppivine } & 8 / 4 / 99 \\ \text { M.R. Porer, Author } & \text { Date }\end{array}$

Waste Processing Technology

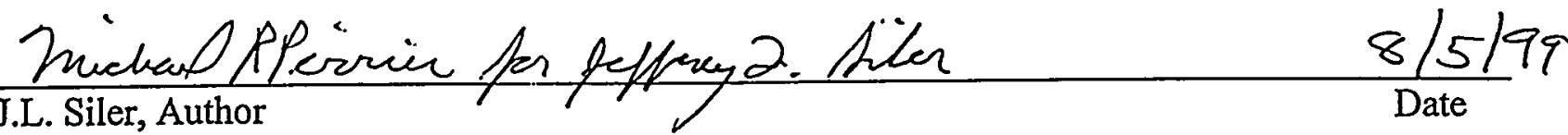

Waste Processing Technology

Could Nash

C.A. Nash; Peer Reviewer

Waste Processing Technology
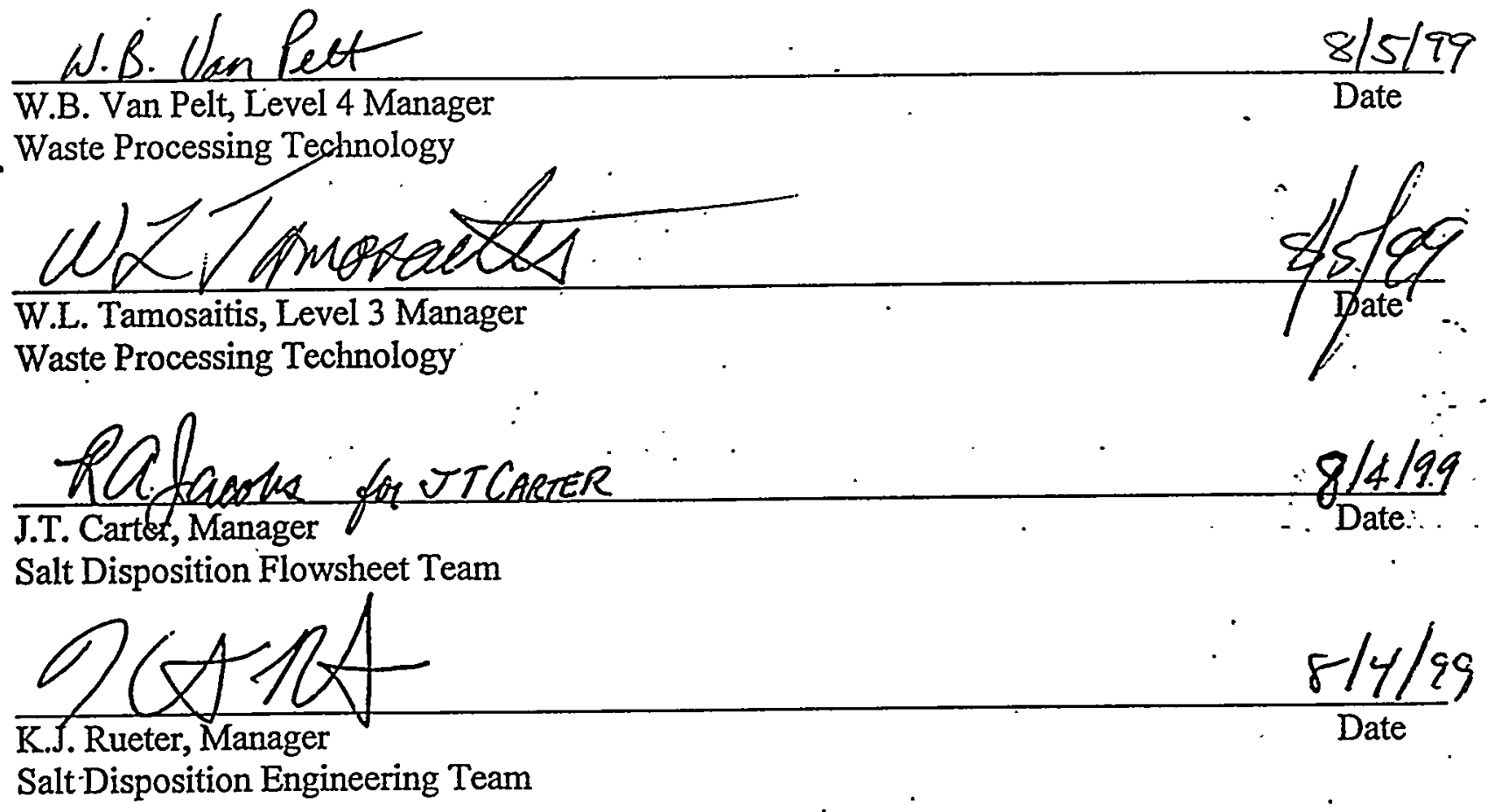


\section{TABLE OF CONTENTS}

\section{RESULTS AND DISCUSSION}

Filtration Performance During Continuous Concentration ....................... 5

Filtration Performance During Constant Volume Washing ........................ 11

Filtration Performance Comparison to Previous Work ........................ 17

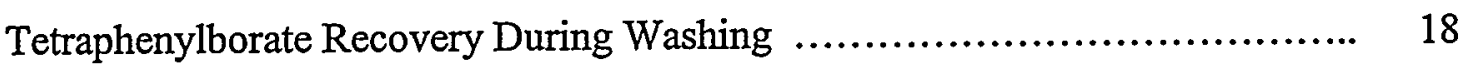

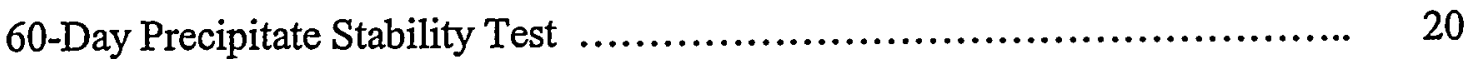

Rheology Measurements ....................................................... $\quad 21$

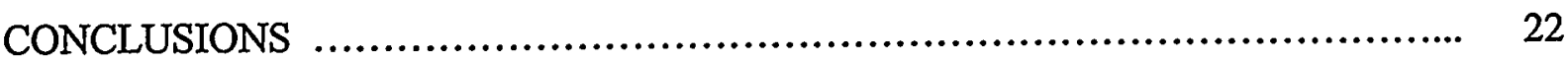

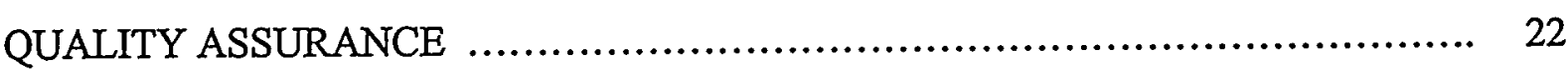

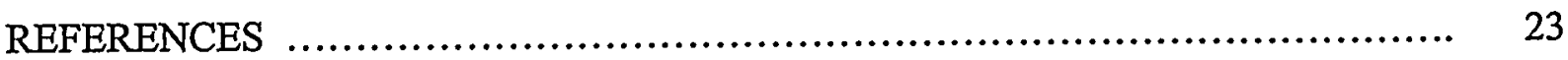

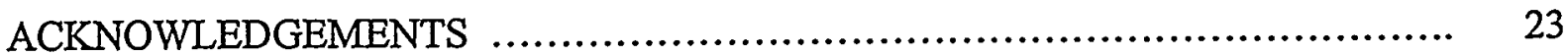




\title{
Continuous Concentration and Constant Volume Washing of Tetraphenylborate Slurries
}

\author{
M.R. Poirier, J.L. Siler \\ Westinghouse Savannah River Company \\ Savannah River Technology Center \\ Aiken, SC 29808
}

\section{SUMMARY}

SRTC has completed filtration testing of tetraphenylborate (TPB) slurries with and without sludge. These tests were slightly different from previous SRS tests in that they used continuous mode concentration and constant volume washing evolutions. The extent of TPB recovery during washing was measured. The resulting washed precipitate slurry, with sludge, was stored at ambient temperature and under a nitrogen-inerted atmosphere to study TPB stability. Samples of both unwashed and washed slurries were submitted for rheology measurements. Key findings from this work are:

- Concentrating TPB slurries containing monosodium titanate but no sludge produced average fluxes in the range of $0.094-0.119 \mathrm{gpm} / \mathrm{ft}^{2}{ }^{2}$ and average permeance values in the range of $0.0075-0.0081 \mathrm{gpm} / \mathrm{ft}{ }^{2} \mathrm{psi}$. Addition of sludge reduced the filtration performance approximately $30-40 \%$.

- Testing generally agreed with past SRS work. Filtration flux responded as expected to changes in axial velocity, transmembrane pressure (TMP), and sludge addition.

- Washing effectiveness was influenced by mixing and Surfynol@ 420 content. Effective mixing of the wash tank is imperative if the slurry is to be effectively washed. Researchers and technicians observed the filter operation to be erratic and difficult to control at the end of each washing evolution.

- Tetraphenylborate (TPB) recovery in spent wash water during precipitate washing was in the range of $62-77 \%$.

- The washed TPB slurry was stable over the 60 -storage period under nitrogen blanket. No TPB decomposition products were formed over the 60-day period.

- Rheology measurements of both unwashed and washed TPB slurries gave yield stress values approximately $1 / 5-1 / 3$ of the value of previous SRS measurements. The effects of shear history, Surfynol ${ }^{\circledR} 420$ concentration, and feed composition may have contributed to the lower rheology measurements.

- Irradiation (33 Mrad) reduced the slurry yield stress.

- Addition of $2 \mathrm{~g} / \mathrm{L}$ Surfynol@ 420 reduced the slurry yield stress. 


\section{RECOMMENDATIONS}

The following is recommended for further study:

- The effects of mixing and Surfynol® 420 addition on precipitate washing should be explored further. Results from the current tests indicate these factors could impact filter performance, TPB recovery during washing, and washed precipitate rheology.

- The NaTPB re-dissolution process should be investigated further to determine the impact of operating parameters and the operating parameters needed to maximize NaTPB recovery.

- Radioactive tests should be performed with actual SRS waste to verify the simulant tests describe the TPB filtration and washing processes adequately.

\section{BACKGROUND}

The Salt Disposition Systems Engineering Team has selected two cesium removal technologies for further development to replace the In-Tank Precipitation process, small tank tetraphenylborate (TPB) precipitation and Crystalline Silicotitanate (CST) ion exchange.

The small tank TPB precipitation process can be described in the following manner: High level waste salt solution, NaTPB, monosodium titanate (MST), dilution water, and recycled wash water will be fed to a continuously stirred tank reactor (CSTR). The discharge from the CSTR will be fed to a second CSTR to complete cesium precipitation to the desired level. The discharge from the second CSTR, a K/CsTPB precipitate $(\sim 0.5 \mathrm{wt} . \%)$ slurry, will be fed to a concentrate tank. The precipitate will be continuously concentrated with a crossflow filter to achieve nominal $10 \mathrm{wt} . \%$ insoluble solids slurry. Periodically, the concentrated precipitate (10 wt.\%) will be transferred to a wash tank where batch washing will reduce the nitrite concentration from 0.41 to $0.01 \mathrm{M} \mathrm{NO}_{2}$. The wash water will be recycled to the first CSTR to reuse recovered NaTPB. The washed precipitate will be transferred to the Defense Waste Processing Facility (DWPF) for vitrification.

High Level Waste requested SRTC to evaluate crossflow filter performance of washed and unwashed $10 \mathrm{wt} . \%$ TPB precipitate slurries containing sludge and MST using the Parallel Rheology Experimental Filter (PREF) at TNX. ${ }^{1}$ The purpose of the test program was to:

- Demonstrate continuous concentration of $4 \mathrm{wt} . \%$ TPB slurry to $10 \mathrm{wt} . \%$.

- Demonstrate constant volume washing of $10 \mathrm{wt} . \%$ TPB slurry.

- Prepare washed precipitate for vitrification testing.

- Determine the filtrate rate of $10 \mathrm{wt.} \%$ unwashed TPB slurry.

- Determine the filtrate rate of $10 \mathrm{wt} . \%$ washed TPB slurry.

- Measure the rheology of unwashed, washed, and irradiated TPB slurries.

- Measure the stability of the TPB slurry over 60 days in the presence of sludge containing noble metals. 


\section{EXPERIMENTAL METHOD}

SRTC prepared the job-specific task and QA plans and conducted the necessary conduct of R\&D. ${ }^{2}$ The unit was modified to allow feed solution to be continuously fed from a separate feed tank to the PREF feed tank. Figure 1a shows the experimental unit and the auxiliary feed tank. The filter was a Mott $0.5 \mu$ crossflow filter with a tube length of 4 feet and a tube inner diameter of 0.5 inches (filter area $0.52 \mathrm{ft}^{2}$ ). The $4.0 \%$ solution was fed to the PREF feed tank through a Masterflex peristaltic pump (see Figure 1b). Figure 1c shows the TPB slurry mixing. Figure 2 shows a schematic of the apparatus.

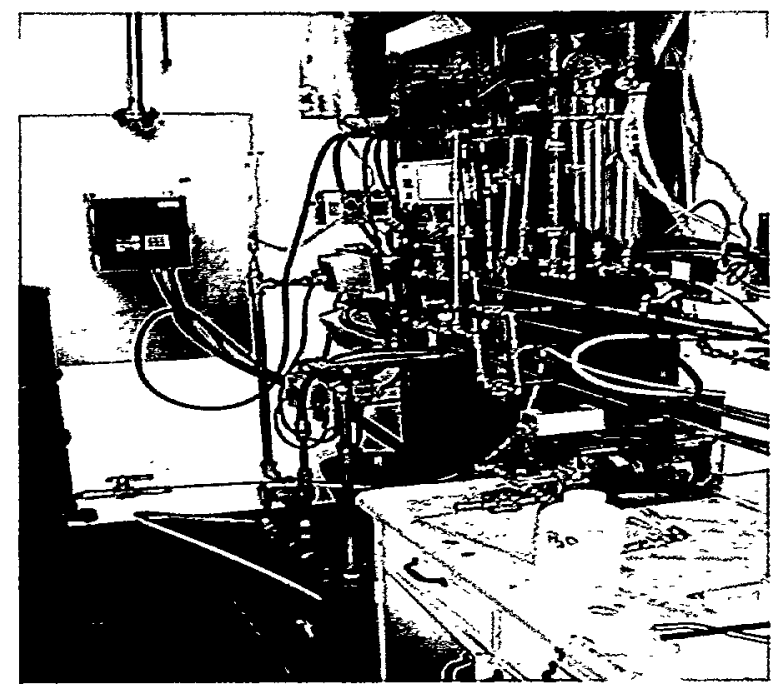

Figure 1a. PREF test unit and auxiliary feed tank.

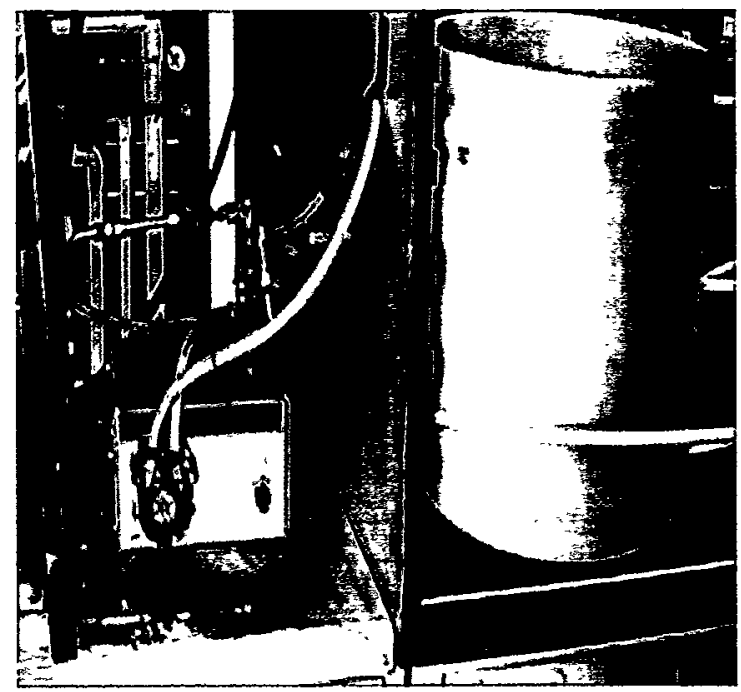

Figure 1b. Masterflex pump used to feed solution to PREF tank.

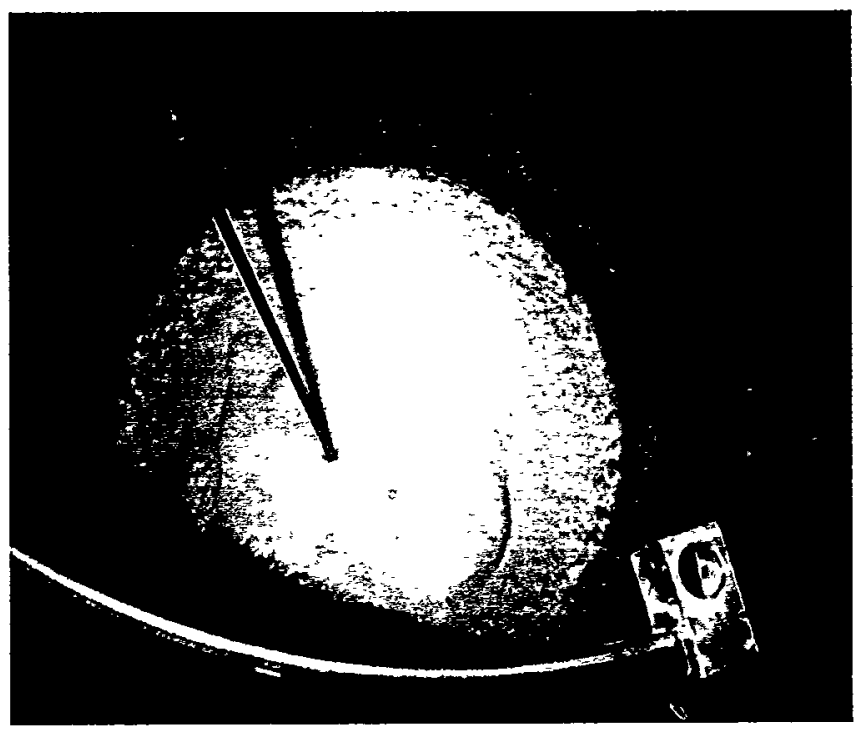

Figure 1c. Tetraphenylborate slurry being stirred prior to testing. 
Figure 2 shows a schematic of the PREF test unit. The system has two filters that can be operated independently or concurrently.

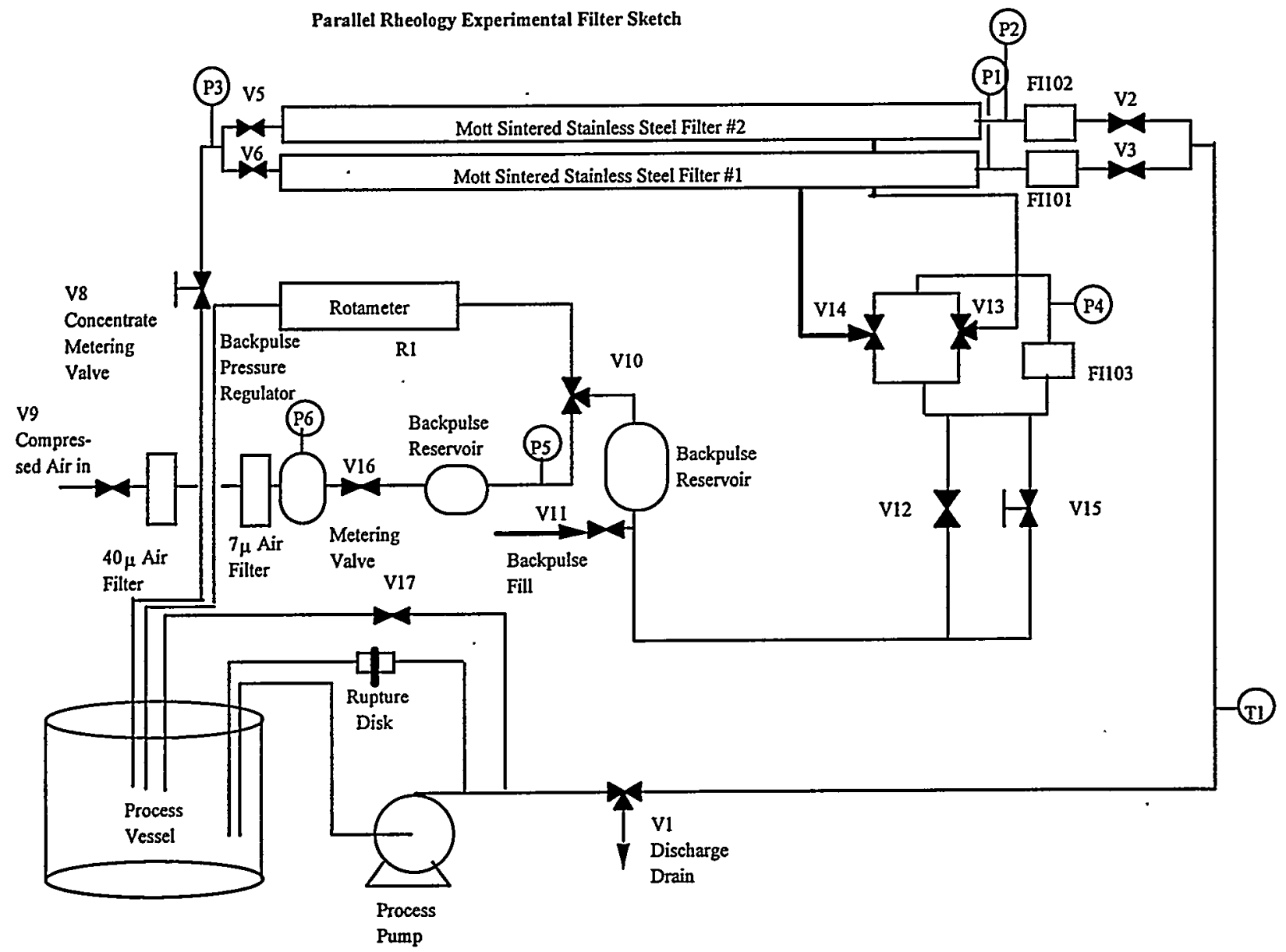

Figure 2. Schematic diagram of PREF test unit.

SRTC prepared salt solution containing $6.1 \mathrm{M} \mathrm{Na}$. The salt solution was mixed with a NaTPB solution $(0.1 \mathrm{M} \mathrm{NaOH}, 0.55 \mathrm{M}$ NaTPB$)$. The recipe provides for $100 \%$ excess NaTPB. Table 1 shows the composition of resulting solution.

SRTC added $20 \mathrm{~L}$ of the $4 \mathrm{wt} \%$ insoluble solids solution to the PREF feed tank. Filtrate was discharged to a drum, while concentrate was returned to the PREF feed tank. The slurry was concentrated to $10 \mathrm{wt} . \%$ insoluble solids (volume reduced to $8 \mathrm{~L}$ ). When the slurry concentration reached $10 \mathrm{wt} . \%$, additional feed was added to the tank at a slightly higher rate than the filtrate was removed in order to keep the insoluble solids concentration constant. The filters were backpulsed every 15 minutes, and the temperature was controlled to $25^{\circ} \pm 2^{\circ} \mathrm{C}$.

Following concentration, The slurry was filtered in total recycle mode (i.e., filtrate returned to PREF feed tank along with the concentrate stream) for 8 hours. During this test, the axial velocity and transmembrane pressure were varied to determine whether they had any significant 
effect on the filtrate rate. The filters were backpulsed every 15 minutes, and the temperature was controlled to $25^{\circ} \pm 2{ }^{\circ} \mathrm{C}$.

Table 1. PREF Feed Solutions

\begin{tabular}{|c|c|c|}
\hline Component & Feed Solution-no sludge & Feed Solution-sludge \\
\hline $\mathrm{OH}$ & $1.48 \mathrm{M}$ & $1.48 \mathrm{M}$ \\
\hline $\mathrm{NO}_{3}$ & $1.66 \mathrm{M}$ & $1.66 \mathrm{M}$ \\
\hline $\mathrm{NO}_{2}$ & $0.40 \mathrm{M}$ & $0.40 \mathrm{M}$ \\
\hline $\mathrm{AlO}_{2}$ & $0.24 \mathrm{M}$ & $0.24 \mathrm{M}$ \\
\hline $\mathrm{CO}_{3}$ & $0.12 \mathrm{M}$ & $0.12 \mathrm{M}$ \\
\hline $\mathrm{SO}_{4}$ & $0.12 \mathrm{M}$ & $0.12 \mathrm{M}$ \\
\hline $\mathrm{Cl}$ & $0.019 \mathrm{M}$ & $0.019 \mathrm{M}$ \\
\hline $\mathrm{F}$ & $0.025 \mathrm{M}$ & $0.025 \mathrm{M}$ \\
\hline $\mathrm{PO}_{4}$ & $0.0077 \mathrm{M}$ & $0.0077 \mathrm{M}$ \\
\hline $\mathrm{C}_{2} \mathrm{O}_{4}$ & $0.0062 \mathrm{M}$ & $0.0062 \mathrm{M}$ \\
\hline $\mathrm{SiO}_{3}$ & $0.0031 \mathrm{M}$ & $0.0031 \mathrm{M}$ \\
\hline $\mathrm{MoO}_{4}$ & $0.00016 \mathrm{M}$ & $0.00016 \mathrm{M}$ \\
\hline $\mathrm{K}$ & $0.062 \mathrm{M}$ & $0.055 \mathrm{M}$ \\
\hline Cs & $0.00011 \mathrm{M}$ & $0.00011 \mathrm{M}$ \\
\hline $\mathrm{Na}$ & $4.7 \mathrm{M}$ & $4.7 \mathrm{M}$ \\
\hline $\mathrm{MST}$ & $4.0 \mathrm{~g} / \mathrm{L}$ & $4.0 \mathrm{~g} / \mathrm{L}$ \\
\hline TPB & $0.12 \mathrm{M}$ & $0.11 \mathrm{M}$ \\
\hline Sludge & None & $5.0 \mathrm{~g} / \mathrm{L}$ \\
\hline $\mathrm{RuCl}_{3}$ & None & $18.4 \mathrm{mg} / \mathrm{L}$ \\
\hline $\mathrm{Rh}\left(\mathrm{NO}_{3}\right)_{3}$ & None & $4.8 \mathrm{mg} / \mathrm{L}$ \\
\hline $\mathrm{Pd}\left(\mathrm{NO}_{3}\right)_{2}$ & None & $8.8 \mathrm{mg} / \mathrm{L}$ \\
\hline $\begin{array}{l}\text { Surfynol@ } \\
420\end{array}$ & None & $2.0 \mathrm{~g} / \mathrm{L}$ \\
\hline
\end{tabular}

Following the 8 hour recycle test, the slurry was washed with $0.01 \mathrm{M} \mathrm{NaOH}$ for approximately 24 hours to reduce the nitrite concentration from $0.41 \mathrm{M}$ to $0.01 \mathrm{M}$. The washing was conducted at constant volume. During washing, filtrate samples were collected periodically and submitted to ADS for sodium, nitrite, and NaTPB analyses. Following washing, the precipitate was concentrated to $10 \mathrm{wt} . \%$ insoluble solids, and precipitate samples were collected for vitrification, stability, and rheology analyses. The filters were backpulsed every 15 minutes, and the temperature was controlled to $25^{\circ} \pm 2^{\circ} \mathrm{C}$.

During the concentration, 8 hour recycle, washing, and stability tests with sludge - containing slurries, the system was inerted with nitrogen for safety purposes and because the palladium catalyst activates faster under nitrogen. 


\section{RESULTS AND DISCUSSION}

\section{Filtration Performance during Concentration}

During the concentration tests performed on March 25 and March 31 (without sludge), the authors measured a filter flux of $0.094-0.119 \mathrm{gpm} / \mathrm{ft}^{2}\left(0.0075-0.0081 \mathrm{gpm} / \mathrm{ft}^{2} \mathrm{psi}\right.$ permeance). As shown in Figures $3 \mathrm{a}$ and $3 \mathrm{~b}$, the filter flux was relatively steady during the concentration and was $0.121 \mathrm{gpm} / \mathrm{ft}^{2}\left(0.0081 \mathrm{gpm} / \mathrm{ft}^{2} \mathrm{psi}\right)$ after concentrating to $10 \mathrm{wt} . \%$ insoluble solids. The differences between the initial and final filter flux are within the experimental uncertainty. Previous SRTC work (WSRC-TR-95-77) with $4.2 \mathrm{wt. \%}$ and $9.3 \mathrm{wt} \%$ insoluble solids measured filter fluxes of $0.056 \mathrm{gpm} / \mathrm{ft}^{2}\left(0.0014 \mathrm{gpm} / \mathrm{ft}^{2} \mathrm{psi}\right.$ permeance $)$ and $0.04 \mathrm{gpm} / \mathrm{ft}^{2}\left(0.001 \mathrm{gpm} / \mathrm{f}^{2} \mathrm{psi}\right)$, respectively. The filter fluxes and permeances in this work are higher than in previous work. The most likely reason for the differences is the higher axial velocity in this test.
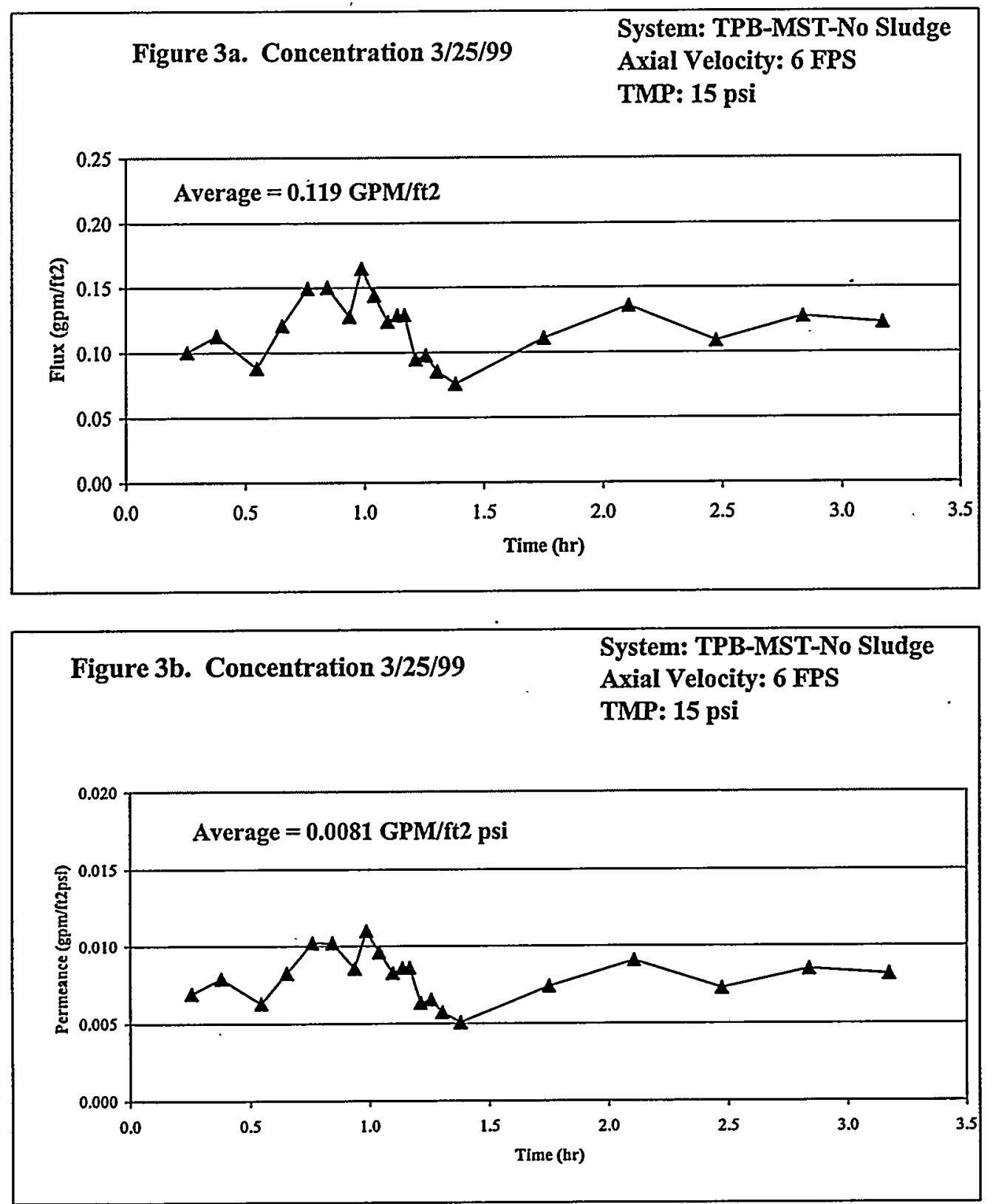
Figure 4 shows the filter flux and permeance during the 8 hour recycle test performed on March 26, 1999 with TPB precipitate containing no sludge. The filter performance was as expected. As the axial velocity and transmembrane pressure (TMP) are increased from $6 \mathrm{ft} / \mathrm{s}$ and $15 \mathrm{psi}$ to $8 \mathrm{ft} / \mathrm{s}$ and 30 psi respectively, the flux increases. The increased flux is caused by the higher axial velocity decreasing the cake thickness at the filter surface, and the higher TMP increasing the driving force across the filter. Decreasing the conditions to $4 \mathrm{ft} / \mathrm{sec}$ and 10 psi resulted in a predictable drop in flux. Performance recovered as conditions were returned to $6 \mathrm{ft} / \mathrm{s}$ and $15 \mathrm{psi}$ although not to the extent seen at the beginning of the test which is most likely due to the cumulative effects of fouling over the course of the test. The results are consistent with previous SRTC work. ${ }^{3,6,7}$
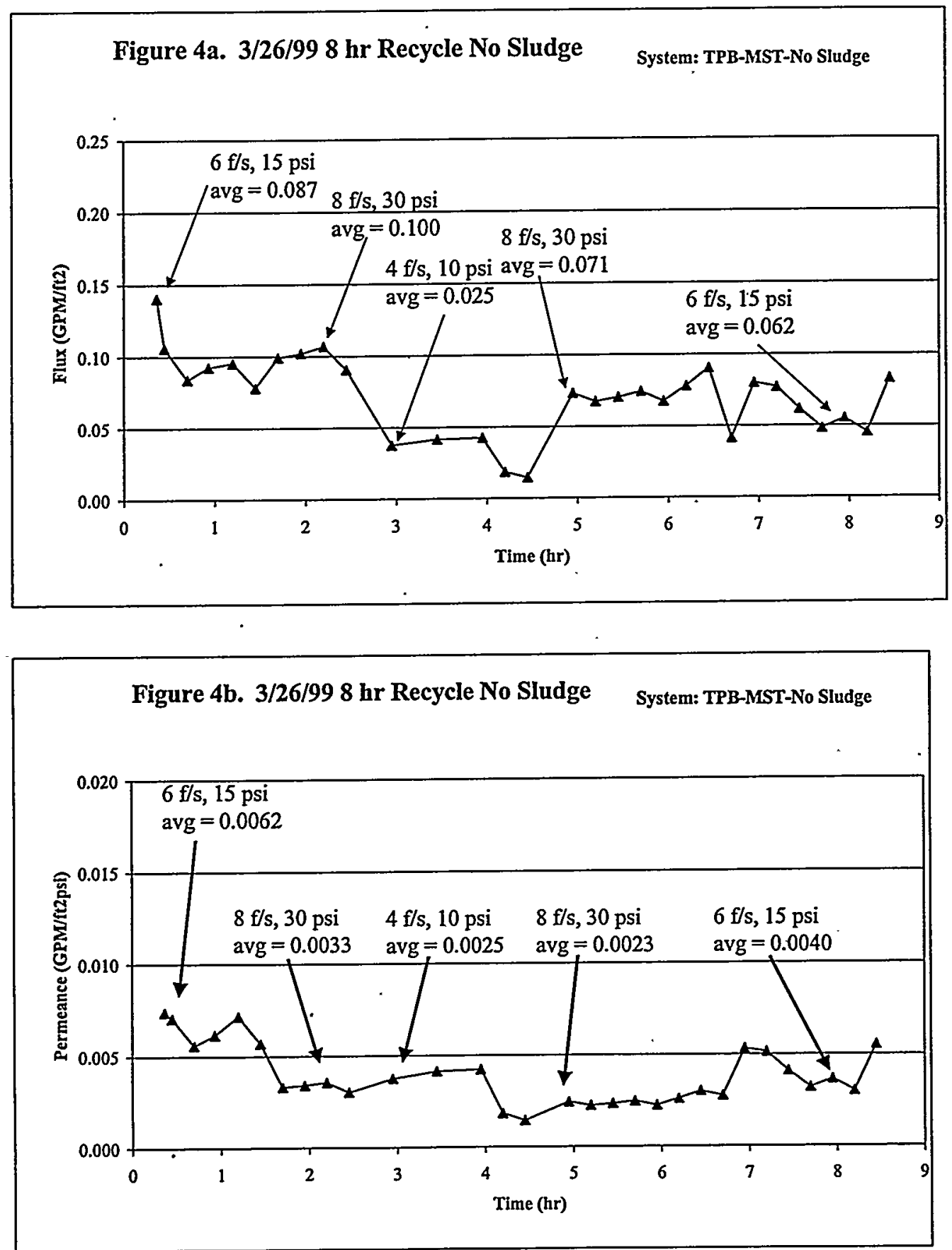
Figure 5 shows the filter flux and permeance during the concentration test performed on March 31,1999 with TPB precipitate containing no sludge. The initial filter flux was approximately $0.126 \mathrm{gpm} / \mathrm{ft}^{2}\left(0.023 \mathrm{gpm} / \mathrm{ft}^{2} \mathrm{psi}\right)$. The filter flux was $0.128 \mathrm{gpm} / \mathrm{ft}^{2}\left(0.0071 \mathrm{gpm} / \mathrm{ft}^{2} \mathrm{psi}\right)$ after concentrating to $10 \mathrm{wt} . \%$ insoluble solids. The flux drop between 0.5 hours and 2 hours is due to unexplained fluctuations in feed flow. The TMP during this same period was steady. The performance from 2 to 4 hours is comparable to that seen during the concentration test on March 25 (see figure 3).
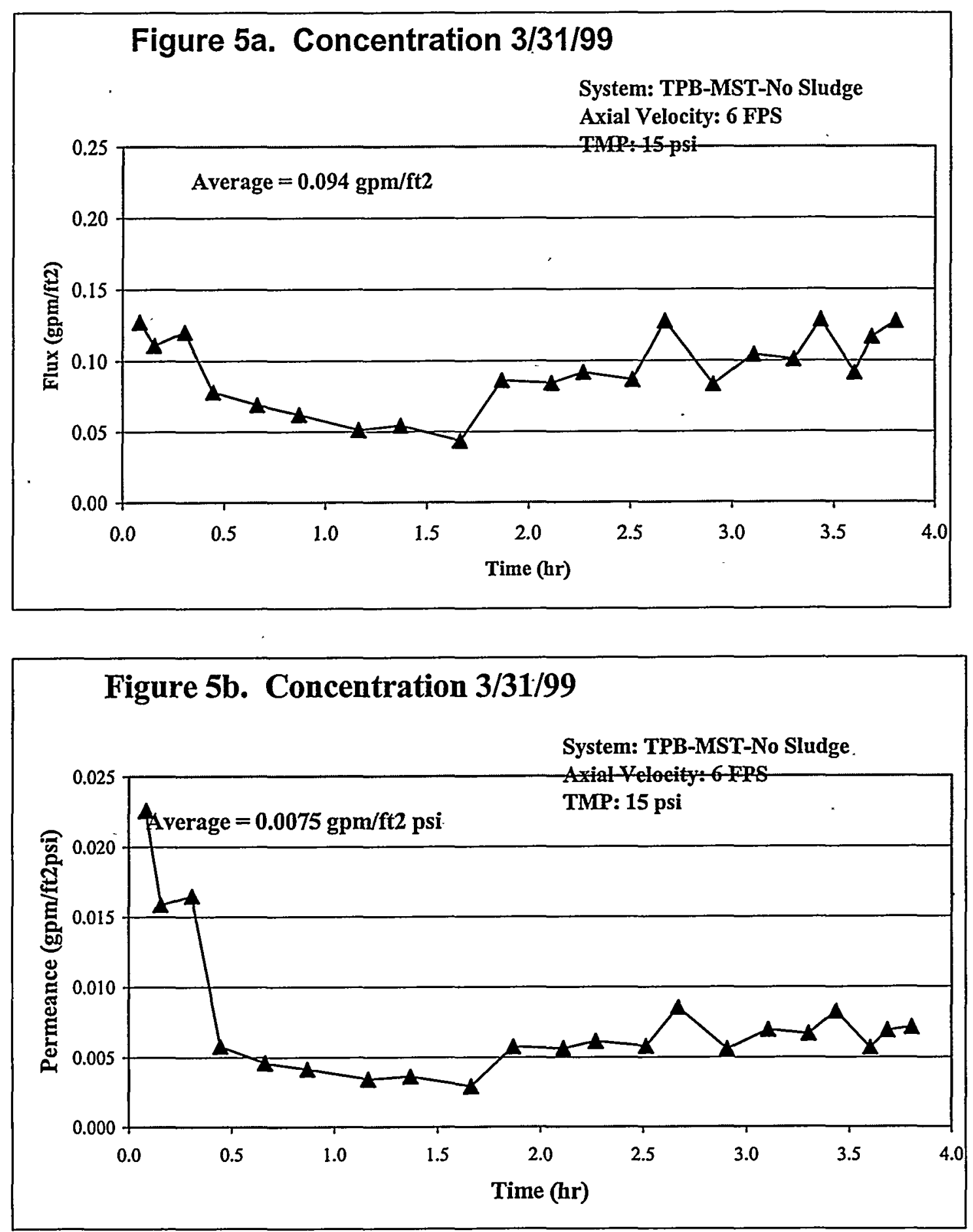
Figure 6 shows the filter flux and permeance during the eight hour recycle test performed on April 1, 1999 with TPB precipitate containing no sludge. As with the previous $8 \mathrm{hr}$. run, the flux and permeance responded in an expected manner from changes in axial velocity and TMP. The response for $8 \mathrm{ft} / \mathrm{s}$ and $30 \mathrm{psi}$ is more pronounced in this test. The permeate flowrate measurement is very sensitive to even slight adjustments to the system such as backpulses and backpressure valve adjustments. Therefore the higher fluxes at $8 \mathrm{ft} / \mathrm{s}$ and $30 \mathrm{psi}$ are believed to be a result of more frequent system adjustment in an attempt to maintain the desired conditions. As seen in Figure $6 \mathrm{~b}$, the permeance response is more damped since the changes in permeate flow from system adjustments are compensated for by corresponding changes in TMP. The flux and permeance at the end of the test (with $6 \mathrm{ft} / \mathrm{sec}$ and $15 \mathrm{psi}$ ) are less than the flux and permeance at the beginning of the test (with $6 \mathrm{ft} / \mathrm{sec}$ and $15 \mathrm{psi}$ ) due to filter fouling.
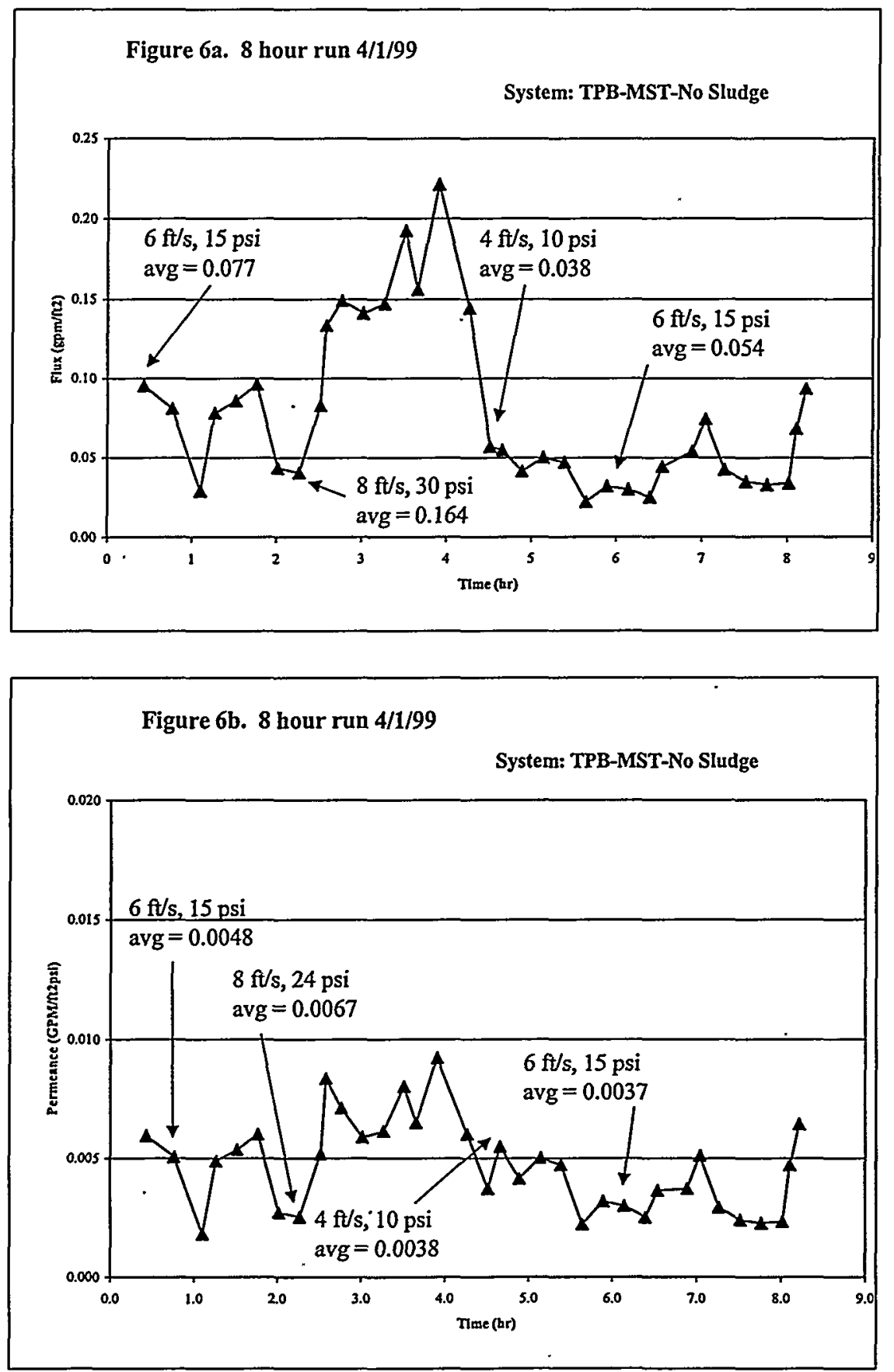
Figure 7 shows the results of the concentration test performed on April 28 (with sludge and nitrogen inerting). The authors measured a filter flux of $0.081 \mathrm{gpm} / \mathrm{ft}^{2}\left(0.0048 \mathrm{gpm} / \mathrm{ft}^{2} \mathrm{psi}\right.$ permeance). This test exhibited more of a fouling behavior near the end of the concentration than did the previous tests. The presence of sludge in this slurry is a likely explanation for the reduction in both flux and permeance. Previous SRTC testing showed the addition of sludge to TPB slurries decreased the filter flux. ${ }^{3,6}$
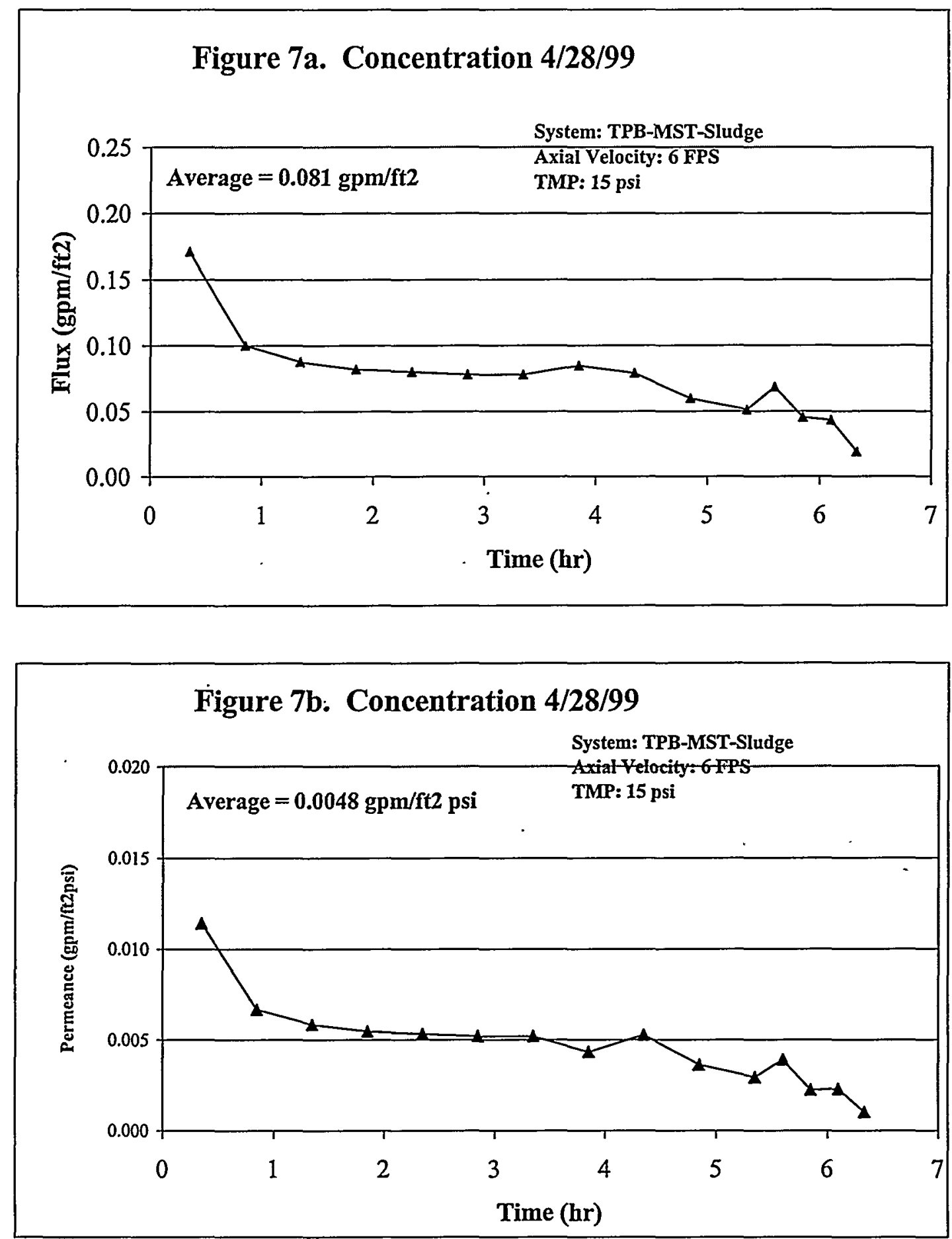
During the 8 hour recycle tests conducted on $4 / 29 / 99$ (see Figures $8 \mathrm{a}$ and $8 \mathrm{~b}$ ), the filter flux and permeance was higher at $6 \mathrm{ft} / \mathrm{s}$ axial velocity and $15 \mathrm{psi}$ TMP than at $4 \mathrm{ft} / \mathrm{s}$ axial velocity and 10 psi TMP. The reason for the increased flux and permeance is the higher axial velocity. When the axial velocity and TMP were increased from $6 \mathrm{ft} / \mathrm{s}$ and $15 \mathrm{psi}$ to $8 \mathrm{ft} / \mathrm{s}$ and $30 \mathrm{psi}$, the filter flux increased from $0.037 \mathrm{gpm} / \mathrm{ft}^{2}$ to $0.046 \mathrm{gpm} / \mathrm{ft}^{2}$ and the permeance remained approximately the same $\left(0.0025 \mathrm{gpm} / \mathrm{ft}^{2}\right.$ psi vs. $\left.0.0028 \mathrm{gpm} / \mathrm{ft}^{2} \mathrm{psi}\right)$. The increased axial velocity was increasing the shear at the filter surface, which swept more of the insoluble solids away from the surface and increased the filter flow rate. The increased TMP increased the driving force across the filter, but the increase was not linear. The increased TMP also caused the filter cake to compact. In this testing, the addition of sludge caused about a $40 \%$ decrease in filter permeance that is consistent with previous SRTC testing. ${ }^{3,6}$ The flux and permeance were higher at the end of the test ( $6 \mathrm{ft} / \mathrm{sec}$ and $15 \mathrm{psi}$ ) than at the beginning. This difference is due to the low filter flow rate during startup.

Figure 8a. 8-hour run 4/29/99

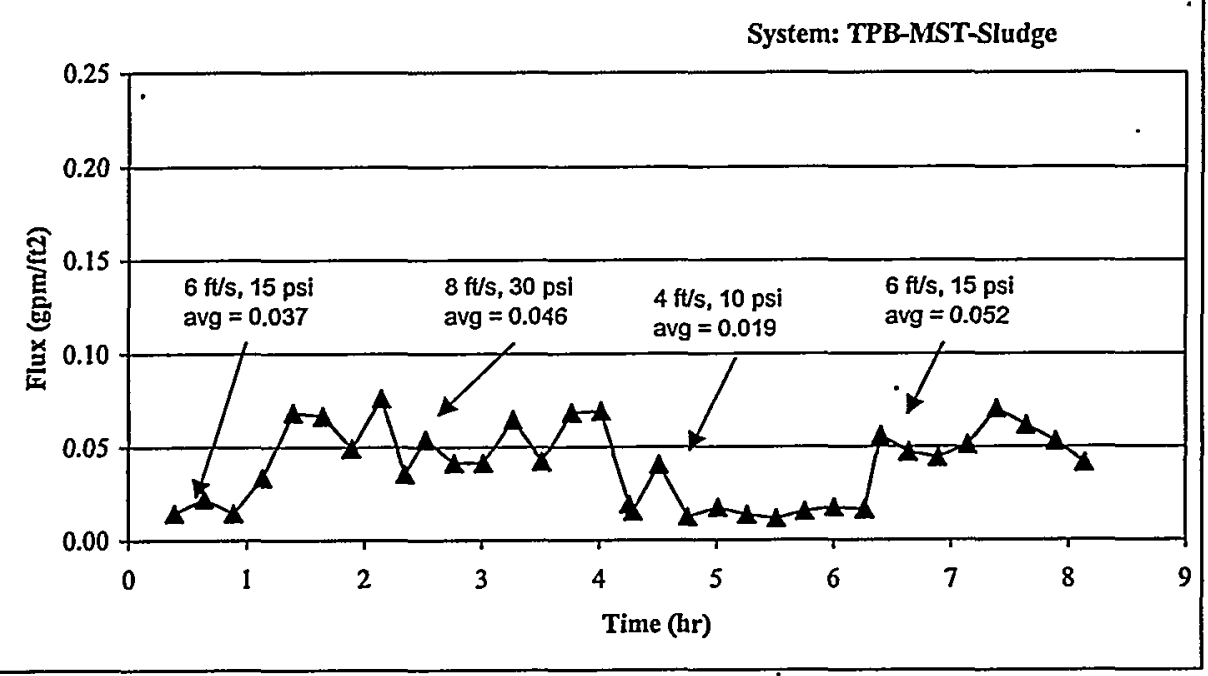

Figure 8 b. 8-hour run 4/29/99

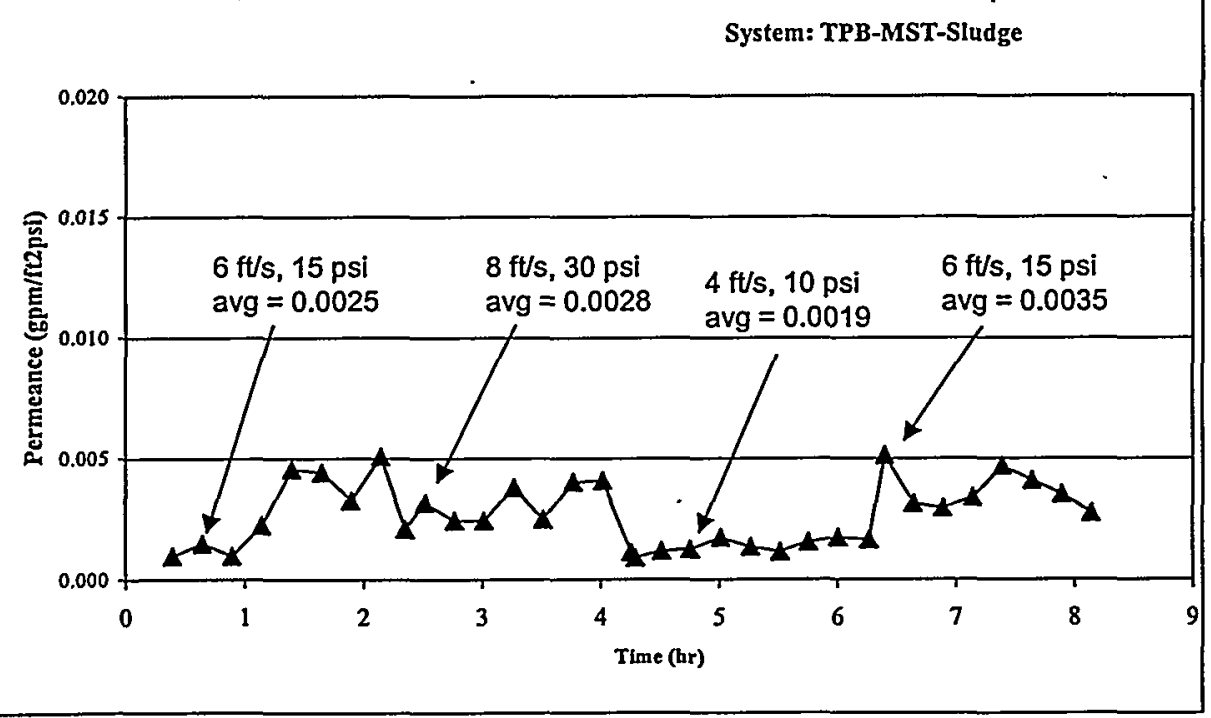




\section{Filtration Performance during Constant Volume Washing}

Following the eight hour recycle test on $4 / 1$, the two $10 \mathrm{wt} \%$ insoluble solids slurries were combined and washed to reduce the nitrite concentration from $0.41 \mathrm{M}$ to $0.01 \mathrm{M}$. The washing was performed by adding $0.01 \mathrm{M} \mathrm{NaOH}$ to the PREF feed tank at the same rate filtrate was removed from the system over 24 hours. Figure 9a shows the filter flux during the washing cycle performed on April 6-7, 1999. The average filter flux was $0.044 \mathrm{gpm} / \mathrm{ft}^{2}(0.0102$ $\mathrm{gpm} / \mathrm{ft}^{2} \mathrm{psi}$ ). The filter flux during washing was much lower than during the concentration and eight hour recycle tests. The reason for the lower flux is the purpose of the test was to wash the precipitate over 24 hours. In order to wash over 24 hours, a filtrate rate of $0.050 \mathrm{gpm} / \mathrm{ft}^{2}$ is needed. The operating parameters (TMP, axial velocity) were adjusted to achieve that rate.
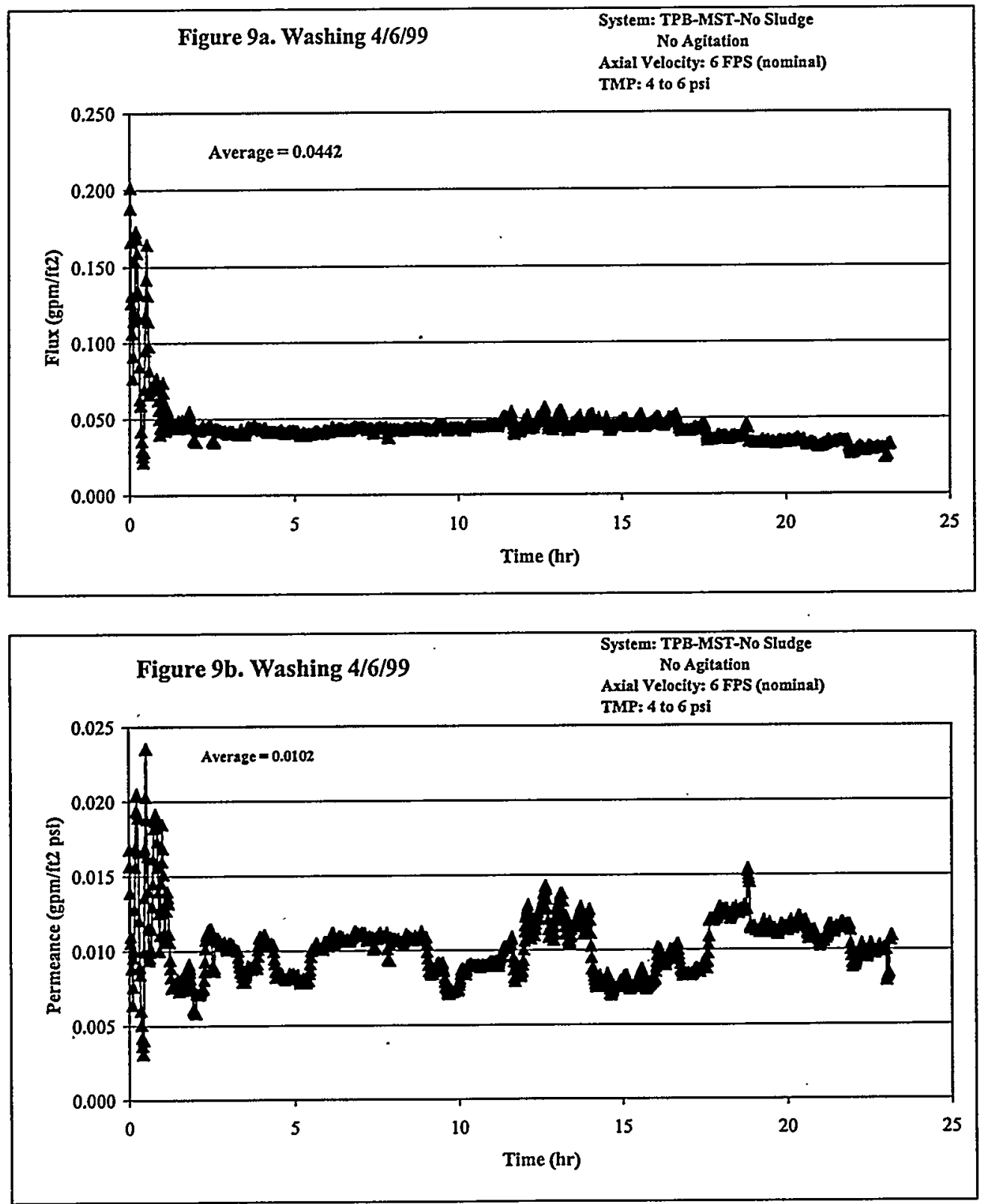
Following the washing, precipitate samples were collected and submitted for analysis. Table 2 shows the analyses. The analyses showed the soluble solids, nitrate, and nitrite concentrations were much higher than expected and the precipitate had not been effectively washed. The reason for the poor washing is the slurry feed tank was not agitated during the washing process. Since the wash water feed line, the filter feed line, and the filter concentrate return line were located at the tank bottom, the wash water and filter concentrate were probably entering the feed tank, and being drawn into the filter feed. This phenomenon is also evident in Figure $9 \mathrm{c}$ which shows a relatively constant feed flow rate consistent with feeding low solids concentration slurry to the filter. The flowrates shown for approximately the first hours are not actually zero, but a startup artifact of the data acquisition system. Little change to the solution and particle characteristics occurred and hence the filter was not significantly challenged during this washing evolution. In effect, only a small fraction of the slurry was washed. In addition to the poor mixing and ineffective washing, the researchers observed foam in the precipitate.

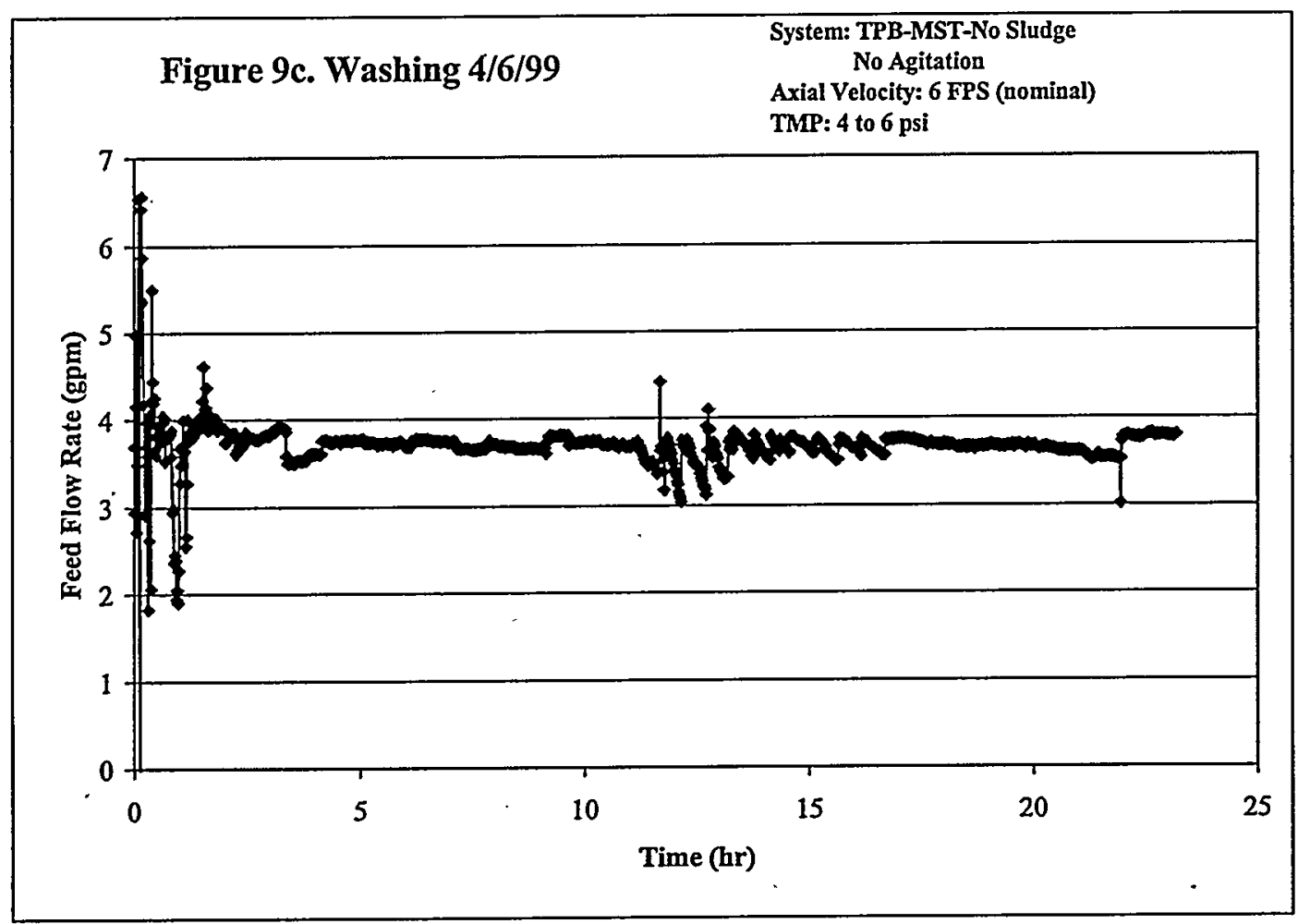

Table 2. Washed Precipitate Analysis

\begin{tabular}{|l|l|l|l|l|}
\hline Component & Wash 4/7/99 & Wash 4/20/99 & Wash 5/3/99 & Target Concentration \\
\hline NO2 & $7100 \mathrm{mg} / \mathrm{L}$ & $33 \mathrm{mg} / \mathrm{L}$ & $10 \mathrm{mg} / \mathrm{L}$ & $460 \mathrm{mg} / \mathrm{L}$ \\
\hline NO3 & $44700 \mathrm{mg} / \mathrm{L}$ & $200 \mathrm{mg} / \mathrm{L}$ & $66 \mathrm{mg} / \mathrm{L}$ & $2542 \mathrm{mg} / \mathrm{L}$ \\
\hline TSS* & $11.53 \mathrm{wt} . \%$ & $13.02 \mathrm{wt} \%$ & $14.13 \mathrm{wt} . \%$ & $10.00 \mathrm{wt} . \%$ \\
\hline TDS** & $14.68 \mathrm{wt} . \%$ & $0.19 \mathrm{wt} . \%$ & $0.18 \mathrm{wt} . \%$ & $0.47 \mathrm{wt} . \%$ \\
\hline
\end{tabular}

* Total Suspended Solids

** Total Dissolved Solids

Because of these results, SRTC added a 3.5 inch diameter axial flow impeller to the PREF feed tank. When the impeller ran at a speed of $300 \mathrm{rpm}$, fluid motion was observed at the slurry 
surface throughout the tank. SRTC also added Surfynol $\otimes^{2} 420(2 \mathrm{~g} / \mathrm{L})$ to the precipitate to eliminate the foam. The addition of Surfynol ${ }^{\circledR} 420$ appeared to make the precipitate less viscous and easier to mix.

The washing cycle was repeated. Following washing, precipitate samples were collected and submitted for analysis. Table 2 shows the analysis. The analysis shows the slurry was effectively washed. Figures $10 \mathrm{a}$ and $10 \mathrm{~b}$ show the filter flux during the washing cycle on April 20-21, 1999. The average filter flux was $0.094 \mathrm{gpm} / \mathrm{ft}^{2}\left(0.0036 \mathrm{gpm} / \mathrm{ft}^{2} \mathrm{psi}\right)$. As the washing cycle proceeded, the precipitate appeared to become more viscous and started to foam. Previous SRTC work has suggested Surfynol ${ }^{\circledR} 420$ decomposes in a high $\mathrm{OH}$ environment. An additional Surfyno ${ }^{\oplus} 420(2 \mathrm{~g} / \mathrm{L})$ was added approximately 7 hours into the test. Following the washing, the precipitate was given to the Immobilization Technology Section for vitrification testing.
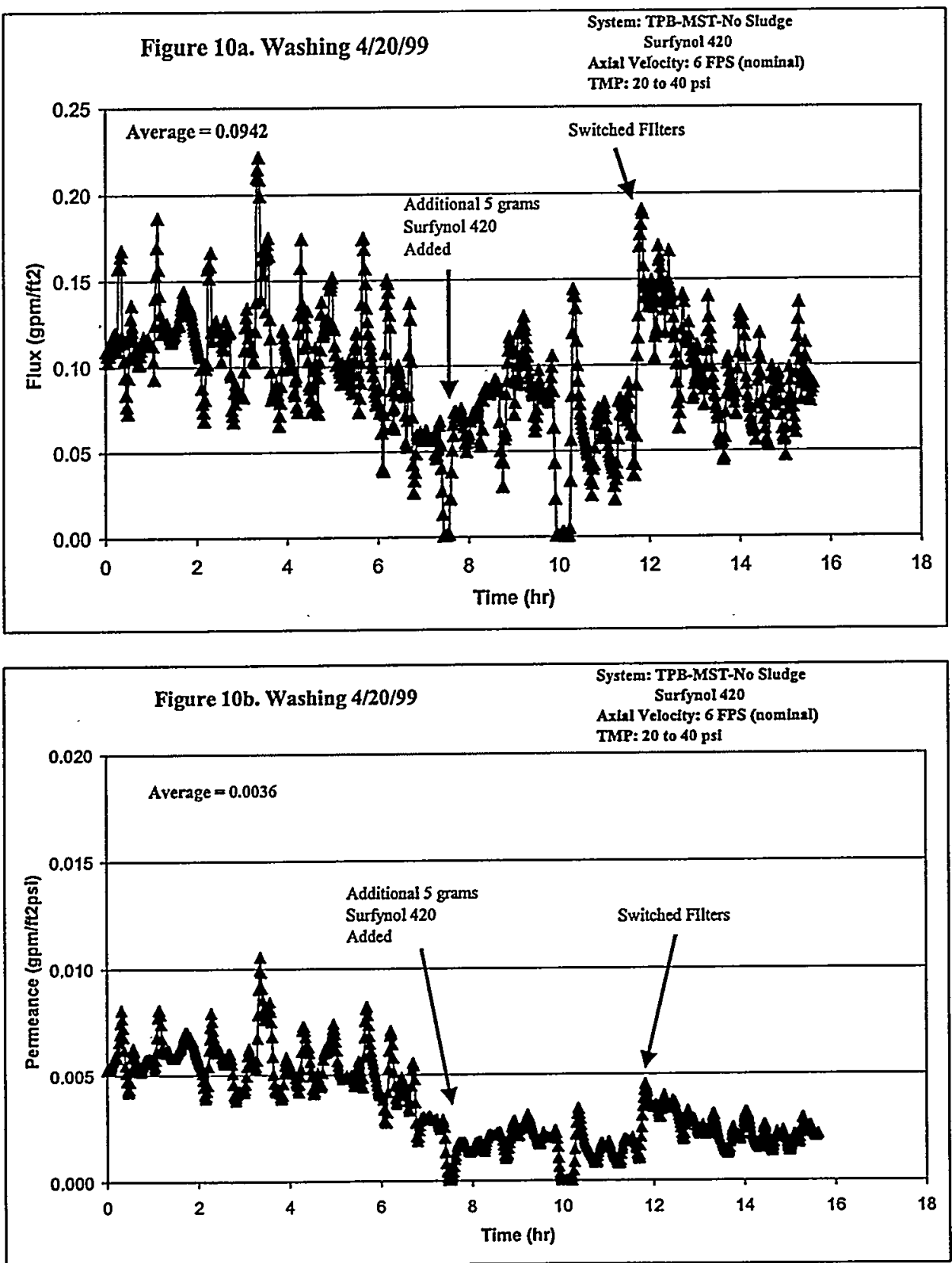
Comparing Figure 10c to Figure 9c shows the drastic effect of feeding a consistently higher solids loading to the filter. The slurry on April 20 had Surfynol ${ }^{\circledR} 420$ added at the beginning of the test and was well agitated throughout the test. Initially feed flows were relatively steady. As filtration continued the flow became much more erratic and difficult to control. As a result of these observations and discussions with researchers in ITS, the authors added Surfynol ${ }^{\circledast} 420$ to the feed slurry and to the wash water during the next washing evolution. The second Surfynol ${ }^{\circledR}$ 420 addition, as mentioned previously, did not improve performance. Concerned that the filter in use may have become severely fouled, the researchers changed from filter 1 to filter 2 . Filter 2 was clean and had not been previously used. The filter performance initially improved after changing filters, but it rapidly declined within a few hours. Possible contributing factors to this behavior include:

- Changing solution and particle characteristics as salt content is reduced during washing.

- Washing effectively removes Surfynol ${ }^{\circledR} 420$, and its beneficial effects, from the system over time.

- High OH decomposes Surfynol ${ }^{\circledR} 420$.

The filters were cleaned with oxalic acid following the washing on April 20, 1999.

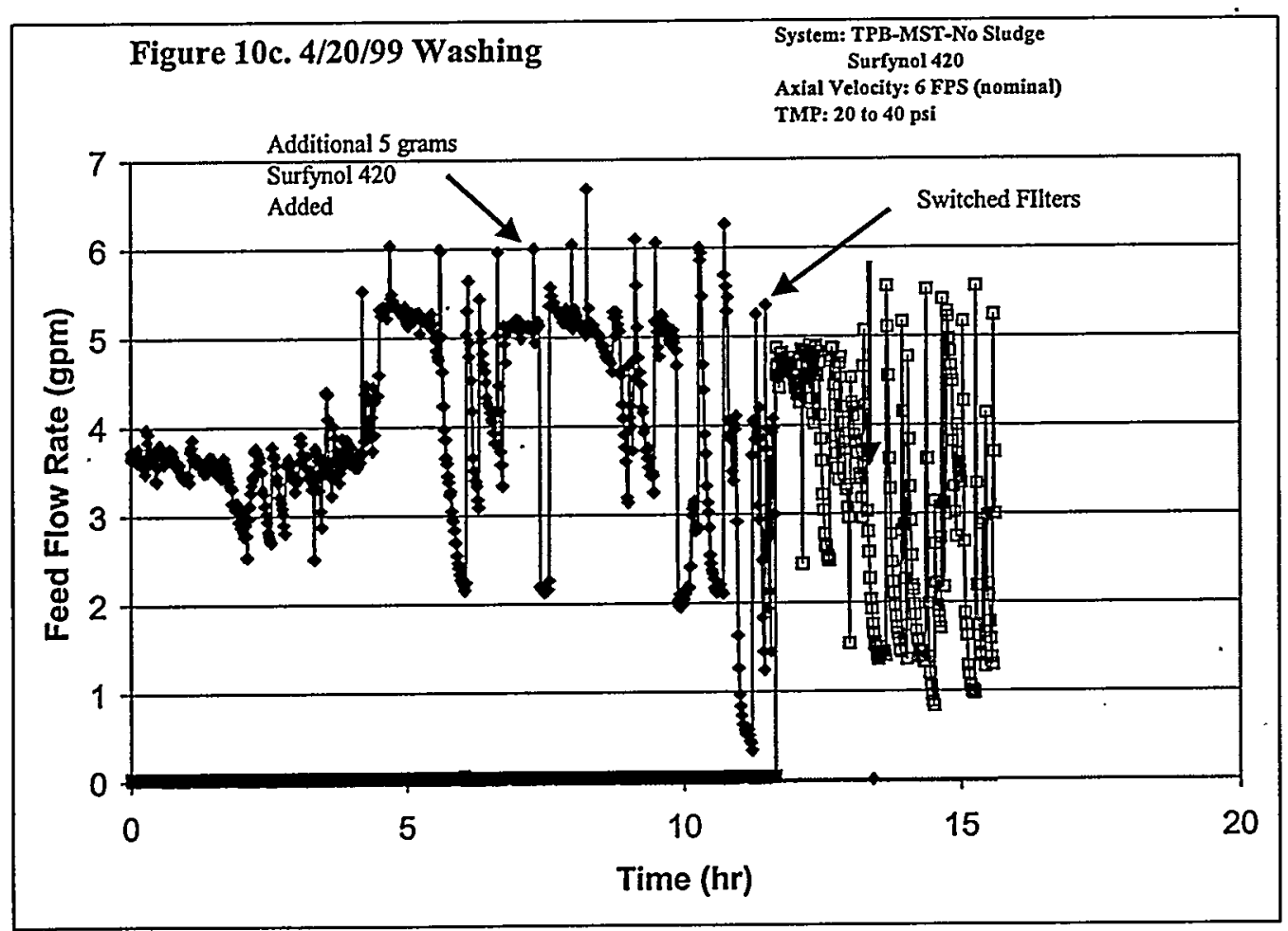

Another batch of precipitate was prepared containing sludge and noble metals (see Table 1). The precipitate also contained $2 \mathrm{~g} / \mathrm{L}$ Surfynol $\Theta 420$. Figure 11 shows the sludge after concentration. 


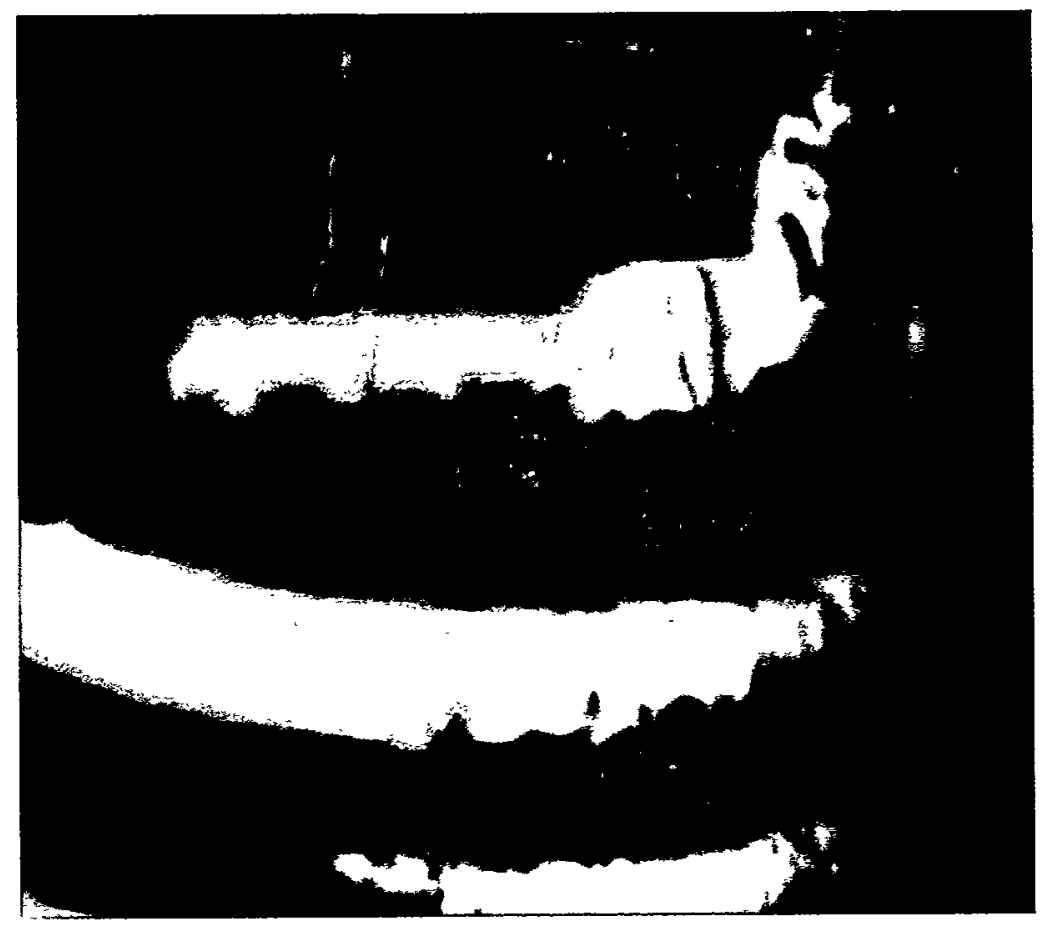

Figure 11. Tetraphenylborate slurry containing sludge and noble metals at $\sim \mathbf{1 0} \%$ solids

Following concentration, the $10 \mathrm{wt} . \%$ insoluble solids slurry was washed to reduce the nitrite concentration from $0.41 \mathrm{M}$ to $0.01 \mathrm{M}$. The washing was performed by adding $0.01 \mathrm{M} \mathrm{NaOH}$ to the feed tank at the same rate filtrate was removed from the system over 24 hours. The wash water also contained Surfynol® $420(0.5 \mathrm{~g} / \mathrm{L})$. Figures $12 \mathrm{a}$ and $12 \mathrm{~b}$ show the filter flux and permeance, respectively, during the washing cycle. The average filter flux was $0.050 \mathrm{gpm} / \mathrm{ft}^{2}$ (Figure 12a) and the average permeance was $0.0038 \mathrm{gpm} / \mathrm{ft}^{2} \mathrm{psi}$ (figure 12b). Table 2 shows the analytical results. Since this slurry was over-washed, it was trimmed with soluble salts to achieve the desired concentrations.

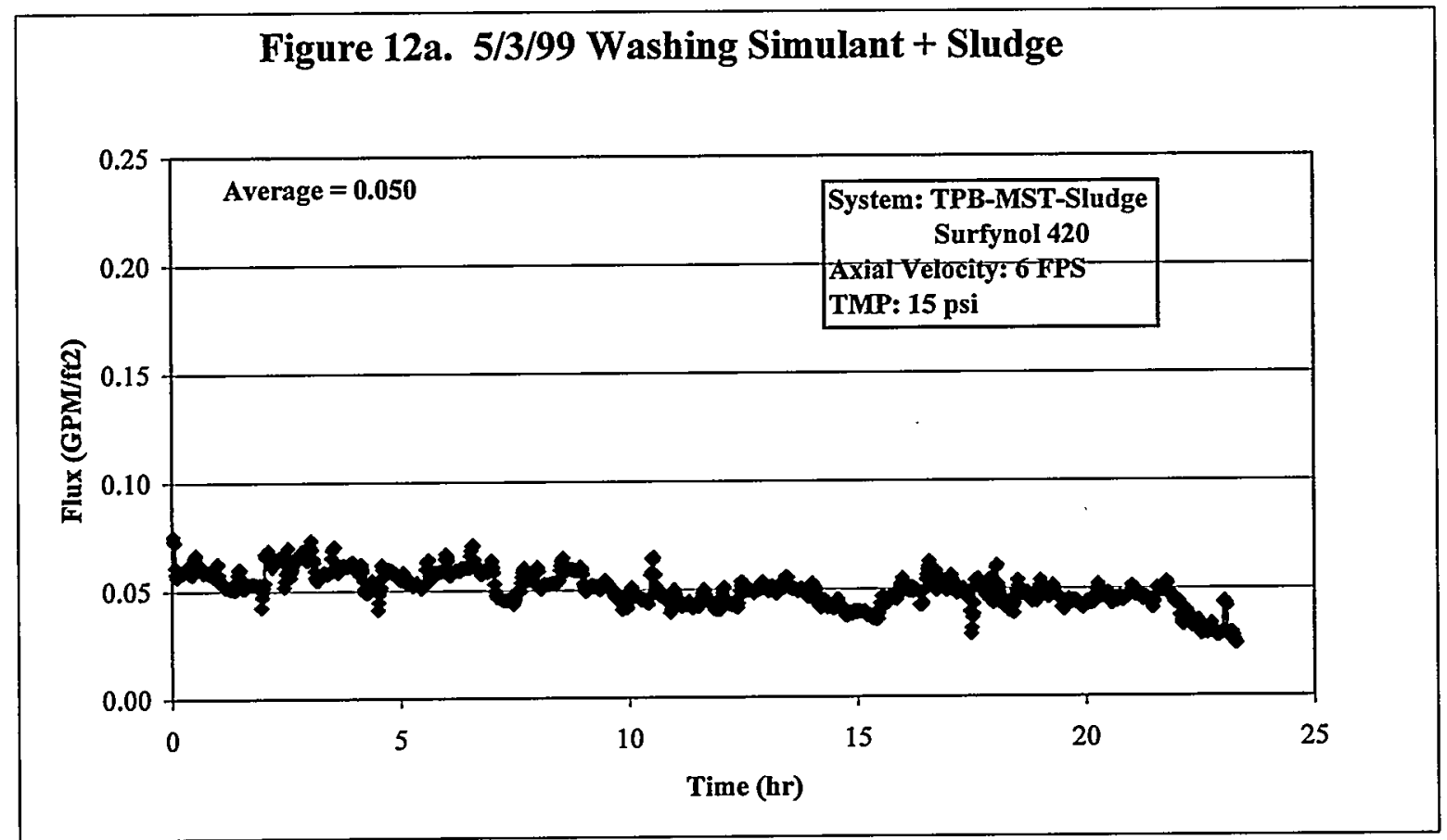



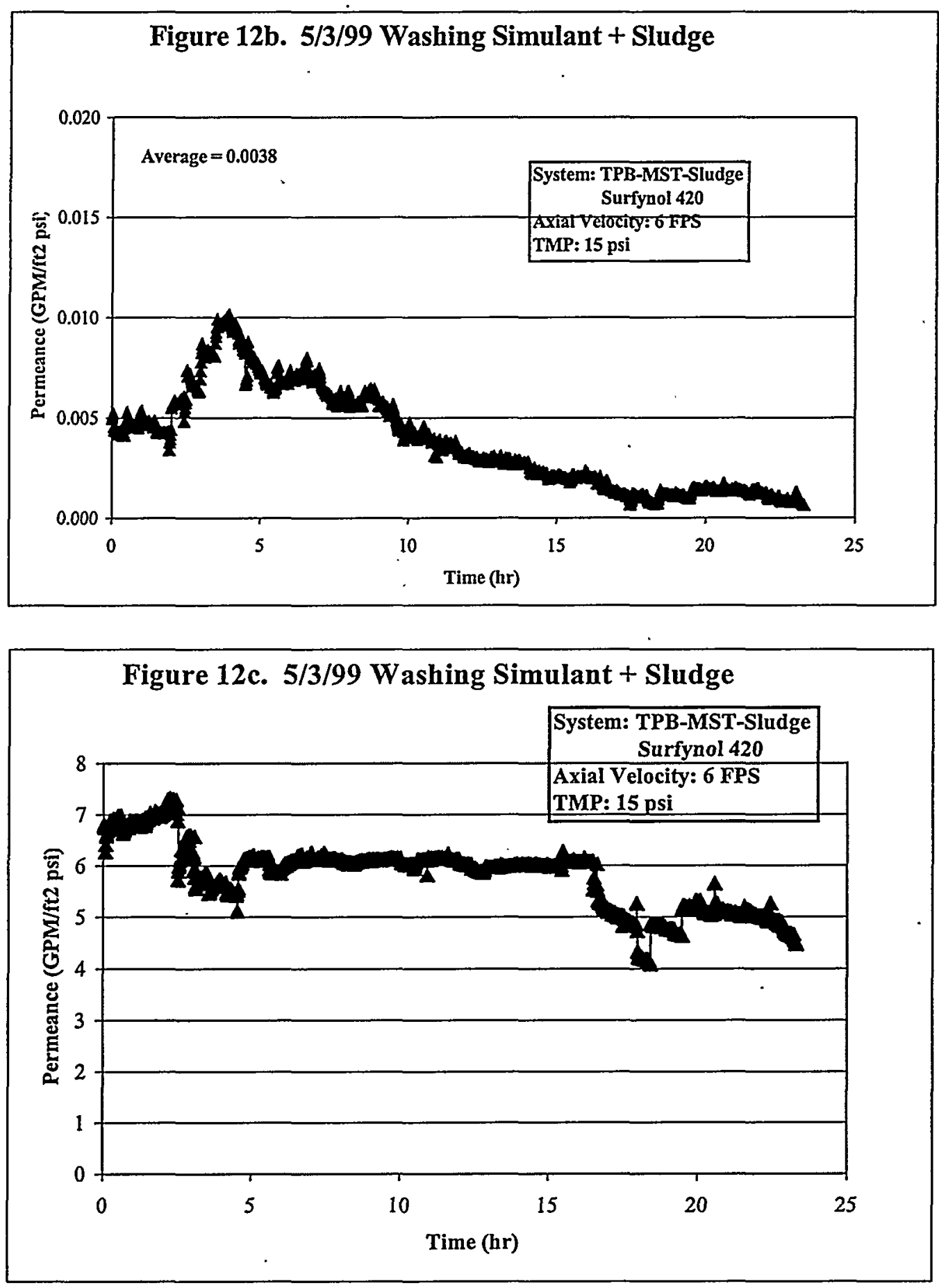

Comparing Figure $12 \mathrm{c}$ to Figure $10 \mathrm{c}$ may indicate a positive filtration effect of adding Surfynol ${ }^{\circledR}$ 420 to the wash water. The feed flow rates were much steadier on the May 3 washing evolution than that of April 20. The presence of sludge in the slurry on May 3 (no sludge on April 20) is a likely cause for the drop in performance near the end of the wash as the filter fouled. Additionally, Surfynol ${ }^{\circledR} 420$ hydrolysis probably occurred which made the slurry more viscous and difficult to filter. 


\section{Filtration Performance Comparison with Previous Work}

Table 3 summarizes the average filtrate flow rate measured during these tests expressed as flux $\left(\mathrm{gpm} / \mathrm{fl}^{2}\right)$ and as permeance $\left(\mathrm{gpm} / \mathrm{ft}^{2} \mathrm{psi}\right)$. The data is presented both ways, because in some cases filter fouling is observed by a reduction in filter flow rate and in other cases it is observed by an increase in transmembrane pressure (TMP). For comparison, the table includes data from previous SRTC filter tests with tetraphenylborate.

Table 3. Filter Flow Rate

\begin{tabular}{|c|c|c|c|c|c|}
\hline Test & $\begin{array}{l}\text { Solids Conc. } \\
\text { (wt. \%) }\end{array}$ & $\begin{array}{c}\text { Axial } \\
\text { Velocity } \\
\text { (ft/s) }\end{array}$ & $\begin{array}{l}\text { TMP Range } \\
\text { (psi) }\end{array}$ & $\begin{array}{l}\text { Avg. Flux } \\
\text { (gpm/ft2) }\end{array}$ & $\begin{array}{l}\text { Avg. Permeance } \\
(\mathrm{gpm} / \mathrm{ft} 2 \mathrm{psi})\end{array}$ \\
\hline Concentration $3 / 25$ & $4-10$ & 6 & $13-15$ & 0.119 & 0.0081 \\
\hline Concentration $3 / 31$ & $4-10$ & 6 & $10-20$ & 0.094 & 0.0075 \\
\hline Concentration $4 / 28$ & $4-10+$ sludge & 6 & $15-20$ & 0.081 & 0.0048 \\
\hline Average & & & & 0.098 & 0.0068 \\
\hline Wash $4 / 6$ & 10 & 6 & $10-40$ & 0.044 & 0.0102 \\
\hline Wash 4/20 & 10 & $6-8$ & $40-60$ & 0.094 & 0.0036 \\
\hline Wash $5 / 3$ & $10+$ sludge & $6-10$ & $10-40$ & 0.050 & 0.0038 \\
\hline Average & & & & 0.064 & 0.0060 \\
\hline $10 \mathrm{wt} \% 6 \mathrm{ft} / \mathrm{s} 3 / 26$ & 10 & 6 & 15 & 0.087 & 0.0062 \\
\hline $10 \mathrm{wt} \% 6 \mathrm{ft} / \mathrm{s} 3 / 26$ & 10 & 6 & 15 & 0.062 & 0.0040 \\
\hline $10 \mathrm{wt} \% 6 \mathrm{ft} / \mathrm{s} 4 / 1$ & 10 & 6 & 15 & 0.077 & 0.0048 \\
\hline $10 \mathrm{wt} \% 6 \mathrm{ft} / \mathrm{s} 4 / 1$ & 10 & 6 & 15 & 0.054 & 0.0037 \\
\hline $10 \mathrm{wt} \% 6 \mathrm{ft} / \mathrm{s} 4 / 29$ & $10+$ sludge & 6 & 15 & 0.037 & 0.0025 \\
\hline $10 \mathrm{wt} \% 6 \mathrm{ft} / \mathrm{s} 4 / 29$ & $10+$ sludge & 6 & 15 & 0.052 & 0.0035 \\
\hline Average & & & & 0.062 & 0.0040 \\
\hline & & & & & \\
\hline $10 \mathrm{wt} \% 8 \mathrm{ft} / \mathrm{s} 3 / 26$ & 10 & 8 & 30 & 0.100 & 0.0033 \\
\hline $10 \mathrm{wt} \% 8 \mathrm{ft} / \mathrm{s} 3 / 26$ & 10 & 8 & 30 & 0.071 & 0.0023 \\
\hline $10 \mathrm{wt} \% 8 \mathrm{ft} / \mathrm{s} 4 / 1$ & 10 & 8 & 30 & 0.164 & 0.0067 \\
\hline $10 \mathrm{wt} \% 8 \mathrm{ft} / \mathrm{s} 4 / 29$ & $10+$ sludge & 8 & 30 & 0.046 & 0.0028 \\
\hline Average & & & & 0.096 & 0.0038 \\
\hline & & & & & \\
\hline $10 \mathrm{wt} \% 4 \mathrm{ft} / \mathrm{s} 3 / 26$ & 10 & 4 & 10 & 0.025 & 0.0025 \\
\hline $10 \mathrm{wt} \% 4 \mathrm{ft} / \mathrm{s} 4 / 1$ & 10 & 4 & 10 & 0.038 & 0.0038 \\
\hline $10 \mathrm{wt} \% 4 \mathrm{ft} / \mathrm{s} 4 / 29$ & $10+$ sludge & 4 & 10 & 0.019 & 0.0019 \\
\hline Average & & & & 0.027 & 0.0027 \\
\hline & & & & & \\
\hline WSRC-TR-95-317 & $10+$ sludge & 6 & $15-45$ & $0.07-0.16$ & $0.0024-0.0055$ \\
\hline WSRC-TR-93-424 & $10+S T$ & & 15 & $0.03-0.06$ & $0.0030-0.0040$ \\
\hline WSRC-TR-95-77 & 9.3 & 3 & 40 & 0.04 & 0.001 \\
\hline WSRC-TR-95-77 & 4.2 & 3 & 40 & 0.056 & 0.0014 \\
\hline WSRC-TR-95-77 & $8.75+$ sludge & 3 & 40 & 0.022 & 0.00055 \\
\hline WSRC-TR-95-77 & $4+$ sludge & 3 & 40 & 0.036 & 0.0009 \\
\hline WSRC-TR-95-420 & 10-Late Wash & 5.8 & 29 & 0.10 & 0.0034 \\
\hline WSRC-TR-95-483 & 8 & 3 & $3-4$ & & 0.004 \\
\hline
\end{tabular}


Concentration tests on March 25 and 31 concentrating TPB slurries without sludge obtained flux values on the range of $0.094-0.119 \mathrm{gpm} / \mathrm{ft}^{2}$ and permeance values in the range of $0.0075-$ $0.0081 \mathrm{gpm} / \mathrm{ft}^{2} \mathrm{psi}$. This compares favorably with previous SRTC work ${ }^{3,4}$ with $4.2 \mathrm{wt} \%$ and 8 wt.\% slurries where the flux was $0.056 \mathrm{gpm} / \mathrm{ft}^{2}$ and permeance ranged from $0.0014-0.0040$ $\mathrm{gpm} / \mathrm{ft}^{2} \mathrm{psi}$. The reason for the higher fluxes and permeances in this test is the higher axial velocity.

Recycle tests at 10 wt.\%, with no sludge, conducted on March 26 and April 1 obtained flux values in the range of $0.025-0.164 \mathrm{gpm} / \mathrm{ft}$ and permeance values in the range of $0.0025-$ $0.0067 \mathrm{gpm} / \mathrm{ft}^{2}$ psi. Again, these results agree with previous tests ${ }^{3,5}$ with $9.3 \mathrm{wt} . \%$ slurry and 10 wt.\% with monosodium titanate (MST) where flux ranged from $0.030-0.060 \mathrm{gpm} / \mathrm{ft}$ and permeance values in the range of $0.0030-0.0040 \mathrm{gpm} / \mathrm{ft}^{2} \mathrm{psi}$.

Concentration tests with sludge on April 28, produced an average flux of $0.081 \mathrm{gpm} / \mathrm{ft}$ and average permeance of $0.0048 \mathrm{gpm} / \mathrm{ft}^{2}$ psi. Past tests ${ }^{3}$ with $4 \mathrm{wt} . \%$ and $8.75 \mathrm{wt} . \%$ slurries with sludge produced flux values in the range of $0.022-0.036 \mathrm{gpm} / \mathrm{ft}$ and permeance values in the range of $0.00055-0.0009 \mathrm{gpm} / \mathrm{ft}^{2} \mathrm{psi}$. Higher flux and permeance values in the current tests are most likely due to the higher axial velocities, $6-8 \mathrm{ft} / \mathrm{sec}$ in the current tests versus $3 \mathrm{ft} / \mathrm{sec}$ in the previous tests.

Recycle tests at $10 \mathrm{wt} \%$, with sludge, conducted on April 29 produced flux values in the range of $0.019-0.052 \mathrm{gpm} / \mathrm{ft}$ and permeance values in the range of $0.0019-0.0035 \mathrm{gpm} / \mathrm{ft}^{2} \mathrm{psi}$. Previous tests ${ }^{6}$ with 10 wt.\% slurry with sludge produced fluxes ranging from $0.070-0.160$ $\mathrm{gpm} / \mathrm{ft}$ and permeance values in the range of $0.0024-0.0055 \mathrm{gpm} / \mathrm{ft}^{2} \mathrm{psi}$. The previous testing used a higher TMP pressure which would increase the flux, but not the permeance. The previous work also had lower concentrations of sludge and MST than this test $(5 \mathrm{~g} / \mathrm{L}$ sludge and $2.1 \mathrm{~g} / \mathrm{L}$ MST versus $12.5 \mathrm{~g} / \mathrm{L}$ sludge and $10 \mathrm{~g} / \mathrm{L}$ MST in this test) which would explain the lower flux and permeance in the current tests.

In summary, the results of the current testing continue to agree with and substantiate previous filter test data.

\section{Tetraphenylborate Recovery during Washing}

During washing, filtrate samples were collected and analyzed to demonstrate effective washing and measure the re-dissolution of NaTPB. Because the April 4 washing was not effective and the April 20 washing started with less than $4.7 \mathrm{M}$ sodium, only the filtrate samples from the May 3 washing were analyzed for NaTPB re-dissolution. Table 4 shows the analytical results. Figures 13 and 14 show the re-dissolution of TPB as a function of time. Much of the redissolution occurs within a few hours. After 12 hours, $65 \%$ of the initial NaTPB has redissolved, and after 23 hours, $77 \%$ of the initial NaTPB has re-dissolved.

Since the precipitate was over-washed, the target nitrite concentration was reached in 9 hours rather than 24 hours. After 9 hours, $62 \%$ of the NaTPB was re-dissolved. Since the NaTPB does not immediately re-dissolve, more TPB would dissolve if the sodium and nitrite concentrations were reduced to their target concentration over 24 hours rather than 9 hours. 

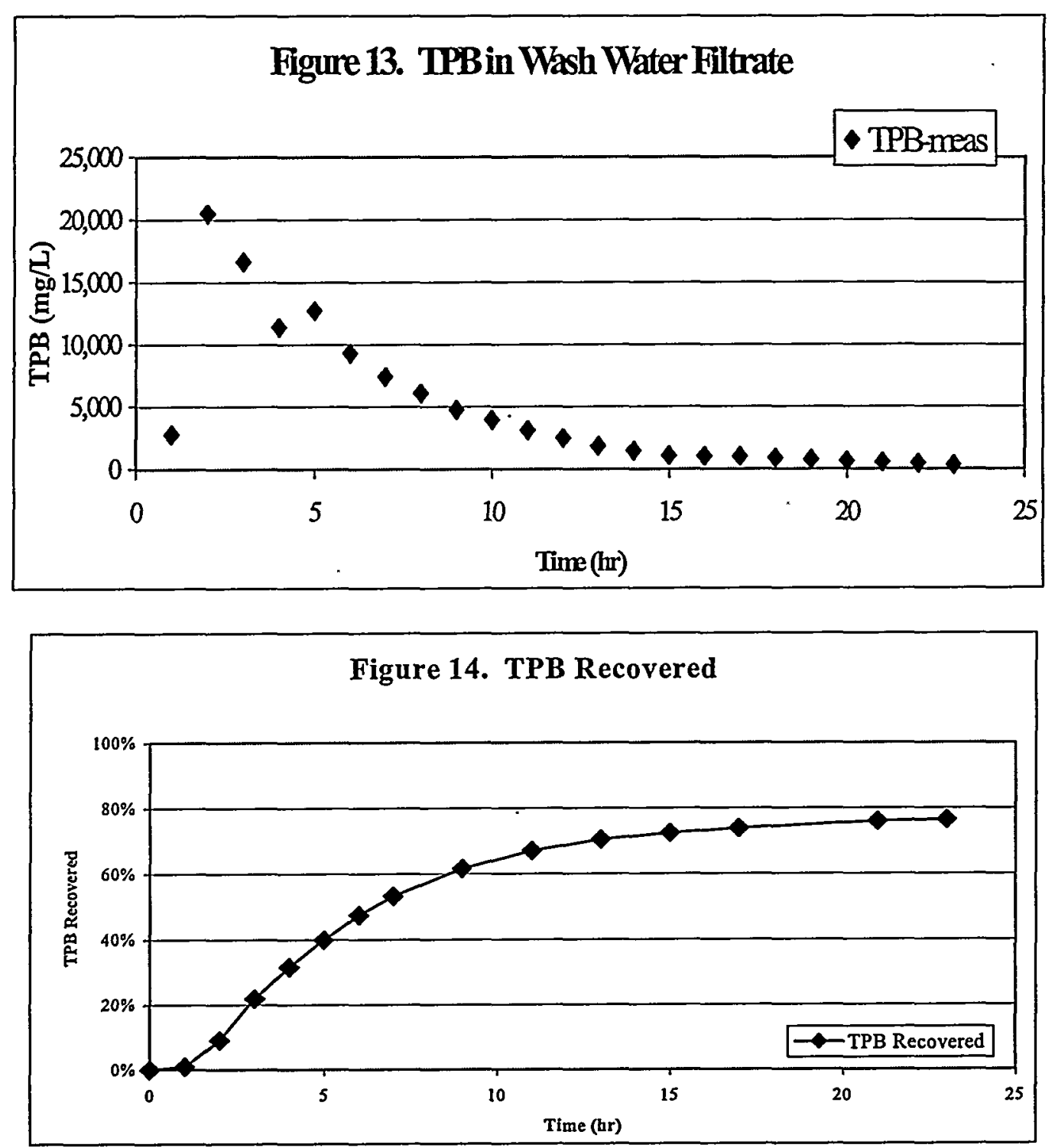

Table 4. NaTPB Re-dissolution

\begin{tabular}{|c|c|c|c|}
\hline Time (hr) & NaTPB (mg/L) & Na (mg/L) & NO2 (mg/L) \\
\hline 1 & 2781 & 80332 & 16406 \\
\hline 2 & 20477 & & \\
\hline 3 & 16637 & & \\
\hline 4 & 11392 & & \\
\hline 5 & 12728 & 9734 & 1729 \\
\hline 6 & 9284 & & \\
\hline 7 & 7411 & & 467 \\
\hline 9 & 4755 & 3201 & \\
\hline 11 & 3118 & & 117 \\
\hline 13 & 1846 & 1103 & \\
\hline 15 & 1073 & & 44 \\
\hline 17 & 985 & 600 & 18 \\
\hline 21 & 540 & 383 & 8 \\
\hline 23 & 319 & 294 & \\
\hline
\end{tabular}


After 23 hours, $77 \%$ of the NaTPB was re-dissolved. Since the sodium concentration was lower than the target, the amount of NaTPB that re-dissolved is probably higher than if the sodium and nitrite concentrations were reduced to their target concentration over 24 hours rather than 9 hours. Additional testing should be conducted to determine the impact of operating parameters on NaTPB recovery and to determine the operating parameters needed to maximize NaTPB recovery.

\section{0-day Precipitate Stability Test}

Another key area of interest was the stability of washed 10 wt.\% slurry (stabilized with $0.01 \mathrm{M}$ $\mathrm{NaOH})$ over a 60-day period stored in inerted conditions and at ambient temperature. Following the May 3 washing evolution, the washed $10 \mathrm{wt} . \%$ precipitate was placed in a storage container under a nitrogen blanket. Precipitate samples were collected periodically and filtered to remove solids. The filtrate from these samples was submitted to ADS for HPLC analysis to measure TPB and its possible decomposition products. TPB decomposition products are soluble and therefore would be present in the sample filtrate if significant TPB degradation had occurred. The samples were refrigerated prior to analysis to minimize any decomposition -after they were collected. Table 5 shows the results. No decomposition of the tetraphenylborate was observed over 61 days.

Table 5. KTPB Precipitate Stability Following 5/3/99 Wash

\begin{tabular}{|l|c|c|c|c|c|c|}
\hline $\begin{array}{c}\text { Sample } \\
\text { Date }\end{array}$ & $\begin{array}{c}\text { Elapsed Time } \\
\text { (days) }\end{array}$ & $\begin{array}{c}\text { TPB } \\
(\mathbf{m g} / \mathbf{L})\end{array}$ & $\begin{array}{c}\text { 3PB } \\
(\mathbf{m g} / \mathbf{L})\end{array}$ & $\begin{array}{c}\mathbf{2 P B} \\
(\mathbf{m g} / \mathbf{L})\end{array}$ & $\begin{array}{c}\text { 1PB } \\
(\mathbf{m g} / \mathbf{L})\end{array}$ & $\begin{array}{c}\text { Phenol } \\
(\mathbf{m g} / \mathbf{L})\end{array}$ \\
\hline $5 / 6 / 99$ & 0 & 424 & $<10$ & $<10$ & $<10$ & $<10$ \\
\hline $5 / 18 / 99$ & 12 & 611 & $<10$ & $<10$ & $<10$ & $<10$ \\
\hline $5 / 21 / 99$ & 15 & 639 & $<10$ & $<10$ & $<10$ & $<10$ \\
\hline $5 / 28 / 99$ & 22 & 710 & $<10$ & $<10$ & $<10$ & $<10$ \\
\hline $6 / 4 / 99$ & 29 & 744 & $<10$ & $<10$ & $<10$ & $<10$ \\
\hline $6 / 4 / 99$ & 29 & 762 & $<10$ & $<10$ & $<10$ & $<10$ \\
\hline $6 / 14 / 99$ & 39 & 765 & $<10$ & $<10$ & $<10$ & $<10$ \\
\hline $6 / 18 / 99$ & 43 & 792 & $<10$ & $<10$ & $<10$ & $<10$ \\
\hline $6 / 22 / 99$ & 47 & 801 & $<10$ & $<10$ & $<10$ & $<10$ \\
\hline $6 / 25 / 99$ & 50 & 812 & $<10$ & $<10$ & $<10$ & $<10$ \\
\hline $6 / 29 / 99$ & 54 & 808 & $<10$ & $<10$ & $<10$ & $<10$ \\
\hline $7 / 1 / 99$ & 56 & 818 & $<10$ & $<10$ & $<10$ & $<10$ \\
\hline $7 / 6 / 99$ & 61 & 816 & $<10$ & $<10$ & $<10$ & $<10$ \\
\hline
\end{tabular}

\section{Rheology Measurements}

Samples of unwashed, washed, and irradiated $10 \mathrm{wt.} \%$ TPB slurries were sent to the University of South Carolina where they were analyzed for both yield stress and consistency. ${ }^{8}$ Samples were tested on a Rheometrics Fluids Spectrometer RFS II using a concentric cylinders device consisting of a stainless steel cup and a titanium bob. Results of these measurements, as well as previous SRS measurements ${ }^{9,10,11}$ of similar slurries for comparison, are given in Table 6. 
Table 6. Comparison of Rheology Measurement Results on TPB Slurries

\begin{tabular}{|l|l|l|l|l|}
\hline & $\begin{array}{l}\text { Temperature, } \\
\mathrm{C}\end{array}$ & $\begin{array}{l}\text { Shear Rate } \\
\text { Applied }\end{array}$ & $\begin{array}{l}\text { Yield Stress, } \\
\text { Dynes/cm2 }\end{array}$ & $\begin{array}{l}\text { Consistency, } \\
\mathrm{cp}\end{array}$ \\
\hline 1999 Unwashed 10 wt\% & 25 & $0-50 \mathrm{sec}^{-1}$ & $20-25$ & $16-24$ \\
\hline 1999 Washed 10 wt\% - sludge & $25-26$ & $0-300 \mathrm{sec}^{-1}$ & $72-85$ & $10-38$ \\
\hline $\begin{array}{l}\text { 1999 Washed 10 wt\% - no } \\
\text { sludge }\end{array}$ & & $0-50 \mathrm{sec}^{-1}$ & $12-20$ & $21-22$ \\
\hline $\begin{array}{l}\text { 1999 Washed 10 wt\% - sludge - } \\
\text { irradiated }\end{array}$ & & $0-50 \mathrm{sec}^{-1}$ & $0-5$ & $5-12$ \\
\hline $\begin{array}{l}\text { 1999 Washed 10 wt\% - sludge - } \\
\text { additional Surfynol 420 }\end{array}$ & & $60-300 \mathrm{sec}^{-1}$ & 38 & 11 \\
\hline 1984 Unwashed 10.3 wt\% & 25 & $0-300 \mathrm{sec}^{-1}$ & $286-330$ & 47 \\
\hline 1984 Unwashed 7.2 wt\% & 25 & $0-300 \mathrm{sec}^{-1}$ & $173-199$ & 33 \\
\hline 1984 Washed 11.3 wt\% & 25 & $0-300 \mathrm{sec}^{-1}$ & $194-426$ & 47 \\
\hline 1984 Washed 8.8 wt\% & 25 & $0-300 \mathrm{sec}^{-1}$ & $151-285$ & 30 \\
\hline 1983 Unwashed 13 wt\% & 20 & $0-300 \mathrm{sec}^{-1}$ & 250 & $60-70$ \\
\hline 1983 ITP Demo 12 wt\% & $24-30$ & $0-128 \mathrm{~min}^{-1}$ & $38-105$ & $17-51$ \\
\hline 1983 ITP Demo 7 wt\% & $24-30$ & $0-128 \mathrm{~min}^{-1}$ & $\begin{array}{l}\text { None } \\
\text { observed }\end{array}$ & 4 \\
\hline
\end{tabular}

The table shows sludge addition increases the slurry yield stress, irradiation (33 Mrad) reduces the slurry yield stress and consistency, and Surfynol $\circledast 420(2 \mathrm{~g} / \mathrm{L})$ reduces the slurry yield stress and consistency.

As seen in the table, the most recent yield stress measurements are approximately a factor of 3 5 lower than most previous results. Consistency values are also lower but to a lesser degree. The current results agree well with the 1983 ITP demonstration sample data, but those earlier samples had radiation exposure which has been shown to reduce both the yield stress and consistency. ${ }^{12}$ These reasons for these differences are not clear although several possible contributing factors can be identified:

- The current samples are of different composition than those from 1983 or 1984. The current samples have less TPB (about $75 \%$ of the total insoluble solids).

- The current samples underwent significant shearing during the concentration and washing evolutions versus the 1983 and 1984 measurements which were made on freshly prepared samples.

- The current washed samples had Surfynol® 420 added where previous samples had no antifoam addition. 


\section{CONCLUSIONS}

Concentrating TPB slurries containing monosodium titanate but no sludge produced average fluxes in the range of $0.094-0.119 \mathrm{gpm} / \mathrm{ft}^{2}$ and average permeance values in the range of $0.0075-0.0081 \mathrm{gpm} / \mathrm{ft}{ }^{2} \mathrm{psi}$. Addition of sludge reduced the filtration performance approximately $30-40 \%$.

Eight hour filtration runs following concentration generally exhibited expected flux responses to changes in axial velocity and transmembrane pressure (TMP). Permeance was less impacted showing that filter performance was more impacted by changes in axial velocity than TMP. .

Washing effectiveness was influenced by the effects of mixing and Surfynol® 420 content as evidenced by the fluctuations in feed rates over the three washing evolutions performed. Filter operation became markedly more erratic and more difficult to control during the final 8 hours of each 24 hour washing evolution. The causes for this behavior are not clear and need further exploration.

The filtration results from these tests were generally consistent with past SRS testing.

Tetraphenylborate (TPB) recovery in spent wash water during precipitate washing was in the range of $62-77 \%$. The extent of mixing and rate of washing are likely influencing factors.

A 60 day stability test was conducted with washed precipitate produced from the filtration tests. The slurry was maintained at ambient temperature and stored in an inert (i.e., nitrogen purged) atmosphere. Analytical results show no loss of TPB and no formation of TPB decomposition products over the 60 day period.

Rheology measurements on unwashed TPB slurries gave yield stress values in the range of 20-25 dynes $/ \mathrm{cm}^{2}$ and consistencies in the range of $16-24 \mathrm{cp}$. Washed slurry samples gave yield stress values in the range of 72-85 dynes $/ \mathrm{cm}^{2}$ and consistencies in the range of 10-38 cp. Irradiation $(33 \mathrm{Mrad})$ reduced the yield stress of washed precipitate to less than 5 dynes $/ \mathrm{cm}^{2}$ and reduced the precipitate consistency to $5-12 \mathrm{cp}$. Addition of $2 \mathrm{~g} / \mathrm{L}$ of Surfynol $\Theta 420$ to the slurry reduced its yield stress to 38 dynes $/ \mathrm{cm}^{2}$ and its consistency to $11 \mathrm{cp}$. While consistency values are consistent with previous SRS testing, the measured yield stresses were approximately $1 / 5-1 / 3$ of the value of previous SRS measurements. The effects of shear history and Surfynol@ 420 concentration may contribute to the lower rheology measurements, but need further study.

\section{QUALITY ASSURANCE}

Results are recorded in WSRC-NB-94-340. Testing was conducted in accordance with SRTC procedures. 


\section{REFERENCES}

1. R. A. Jacobs, "HLW Technical Task Request - Engineering Scale Filtration Studies", HLWSDT-TTR-99-05.0, Rev. 0, February 2, 1999.

2. J. L. Siler and M. R. Poirier, "Task Technical and Quality Assurance Plan for the Salt Alternatives Filtration Testing Using the Parallel Rheology Experimental Filter (PREF)", WSRC-TR-99-00260, March 15, 1999.

3. R. A. Peterson, "Impact of Insoluble Solids on Filtration Performance", WSRC-TR-95-0077, February 28, 1995.

4. C. A. Nash, "Filtration of Tank 48H Contents with a Cells Unit Filter", WSRC-TR-95-0483, December 8, 1995.

5. M. F. Morrissey, “Adding Sodium Titanate to ITP Simulant”, WSRC- 晦-93-424, March 23, 1993.

6. R. A. Peterson, Correlation of Late Wash Simulants Filtrate Flow Rate", WSRC-TR-950317, August 7, 1995.

7. R. A. Peterson and C. A. Nash, "Filter Performance Mechanisms", WSRC-TR:95-0420, October 20, 1995.

8. Francis A. Gadala-Maria and V. Giri Kolli, "Rheology Measurements for Salt Disposition Alternatives," July 1999.

9. B.A. Hamm , "Rheology of Precipitate from Full Scale In-Tank Demonstration," DPST-83955, October 28, 1983.

10. I.D. Goren,"Rheology of Concentrated Tetraphenylborate Precipitate," DPST-83-979, November 4, 1983.

11. M.A. McClain and I.D. Goren, "Rheology of Non-Radioactive Simulant of Concentrated Tetraphenylborate Precipitate," DPST-84-4019, March 30, 1984.

12. D.D. Walker and J.P. Doherty, "The Effects of Gamma Irradiation on the Rheology of KTPB Slurries," DPST-85-926, November 5, 1985.

\section{ACKNOWLEDGEMENTS}

Henry Bolton and Al Gunter, WPT, performed the filtration experiements.

Tom White, ADS, provided tetraphenylborate analyses. 


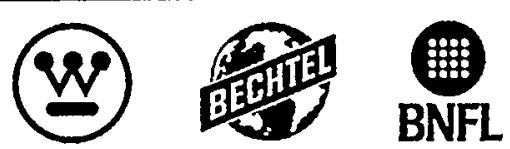

T.M. Monahon, 703-H

J. P. Morin, 703-H

E. T. Murphy, 704-3N

C. A. Nash, 773-42A

L. M. Nelson, 773-43A

L. M. Papouchado, 773-A

W. C. Clark, 704-56H

N. R. Davis, 703-H

M. R. Poirier, 676-T

M. J. Polochko, 773-A

L. O. Dworjanyn, 779-2A

J. Reynolds, 704-196N

H. H. Elder, 704-S

S. D. Fink, 773-A

F. F. Fondeur, 773-62A

J. R. Fowler, 704-3N

W. E. Stevens, 773-A

T. Hang, 773-42A

K. J. Rueter, 706-S

P. L. Rutland, 704-196N

R. H. Spires, 703-H

J. W. McCullough, 703-H

P. C. Suggs, $704-196 \mathrm{~N}$

W. L. Tamosaitis, 773-A

D. T. Hobbs, 773-A

G. A. Taylor, $704-196 \mathrm{~N}$

E. W. Holtzscheiter, 773-A

W. B. VanPelt, 773-43A

P. I. Hudson, 704-3N

R. A. Jacobs, 704-3N

M. D. Johnson, 703-H

D. C. Hannah, 703-46A

D. D. Walker, 773-A

W. R. Wilmarth, 773-42A

G. T. Wright, 773-A

M. G. Schwenker, 703-46A

P. R. Jackson, 703-46A

R. T. Jones, $704-3 \mathrm{~N}$

L. F. Landon, 704-T

B. L. Lewis, 703-H

T. J. Lex, 703-H

D. J. McCabe, 773-42A

TIM, 703-43A

WPTS Files, 773-A, c/o Cathy Canada, 773-A

J. A. Pike, 704-3N

P. E. Lowe, 773-41A

ITP Files c/o Cathy Smalls, 241-147H 